\title{
THE RULE OF REASON, WORKABLE COMPETITION, AND MONOPOLY
}

\author{
GEORGE W. STOCKINGT
}

Agrtation for changing the antitrust laws is as old as the laws themselves, but the intensity of the demand for modification, and its objectives, have varied. The recent clamor for change culminated in the appointment of the Attorney General's National Committee to Study the Antitrust Laws. The most ardent proponents of revision had laid down two principles by which they would have the Sherman Act interpreted: the rule of reason and the concept of workable competition. ${ }^{1}$ This article will sketch briefly the develop-

$\doteqdot$ Director, Institute of Research and Training in the Social Sciences; Chairman, Department of Economics, Vanderbilt University; co-author (WATKr:ss), Mlosoroly A:o FreE ENTERPRise (1951). The author is indebted to Mrs. Elizabeth R. Post, LL.B., Yale 1948, member of the Tennessee Bar, and to Paul T. Bechtol, Jr., graduate assistant in economics, for their help in preparing this article, and to his colleague, Professor James W. McKie, for his critical comments.

1. For an exposition of the rule of reason and the concept of workable competition as modifications of antitrust policy, see Oppenheim, Federal Antitrust Legislation: Guideposts to a Revised National Antitrust Policy, 50 MIICH. L. Rev. 1139 (1952). The eftectiveness of Oppenheim's demand for change is reflected in his having been made co-chairman with Judge Stanley N. Barnes, Assistant Attorney General in charge of the Antitrust Division, of the Attorney General's National Committee to Study the Antitrust Laws. Endorsement of these principles appears in Smith, Effectize Compelition: Hypothesis for Modernizing the Antitrust Laws, 26 N.Y.U.L. REv. 405 (1951) ; U.S. Dep'T OF COMserere, Effective Conipetition: A Report to the Secretary of Conarerce dy His Business Advisory CouncI (1952). See also Adelman, Effectize Compelition and the Antitrust Lazes, 61 Harv. L. Rev. 1289 (1948) ; Sunderland, Changing Legal Concepts in the Ansitrust Field, 3 SyRacuse L. Rev. 60 (1951).

Although the demand for a change in the law to comply with the rule of reason and the concept of workable competition seems to have been the occasion for setting up the Attorney General's Committee, the Committee carefully avoided recommending that the law be modified to conform to the theory of workable competition, cautioning that it "does not provide a standard of legality under any of the antitrust laws." REPORT OF THE ATTOa:ier General's National Conarittee to Study the Antitrust Laws 316 (1955). But having shut out workable competition at the front door, the Committee brought it in by the back. It recognized that "it provides the courts with tools of analysis in making the factual inquiry into problems of competition and monopoly...." Ibid. Blackwell Smith, a member of the Committee, acknowledges more specifically the Committee's endorsement of the concept of workable competition as a legal standard. He says: "The central concept of workable or effective competition is described in the Report in terms which parallel very closely the legal policy statements elsewhere in the Report as to characteristics of acceptable competition"; and that out of the report "comes the most realistic set of standards for legal and socially acceptable competition since the Business Advisory Council Report on Effective Competition published by Secretary of Commerce Sawyer. The present Report malkes more official a great deal of what was then and there recommended." Trade Practice Bulletin, Míay 1955, p. 4. 
ment of these two ideas and analyze their significance to one sector of antitrust policy, that dealing with industrial consolidation and monopoly.

\section{WORKable COMPETITION}

Chamberlin's Theory of Monopolistic Competition, published in 1933, one of the century's really significant contributions to economic thinking, greatly disturbed students of industrial structure and public policy. Other economists had noted with concern the impact of two great merger movements ${ }^{2}$ on the structure of the American economy, but few had recognized with Chamberlin's insight the significance of structure to economic behavior, ${ }^{3}$ and none had developed a satisfactory theory of monopolistic competition. Chamberlin's analysis was disturbing in two respects. On the basis of his very rigorous assumptions $^{4}$ he concluded that (1) oligopolists, if they are rational and take account of both the direct and indirect consequences of their decisions on prices, will without conspiring behave like monopolists; and (2) although rivalry among the producers of differentiated products may eliminate monopoly profits, it will not minimize costs.

No less disturbing than Chamberlin's analysis was the intellectual renction to it. Arthur R. Burns, arguing that contemporary industrial structure is largely a response to modern technology and that its monopolistic character is therefore inevitable, advocated such a comprehensive program of social con$\operatorname{trol}^{5}$ that one of his more severe critics characterized his study as "planning for totalitarian monopoly." Edwin G. Nourse, similarly arguing that modern technology decrees business units so large and so few that market forces cannot be relied on to insure competitive pricing, sought to promote the ptblic welfare by persuading businessmen that their long-run interests lie not in charging what the traffic will bear but in passing on to consumers in the form of lower prices the gains from technological innovation. ${ }^{\top}$ Such measures were not acceptable to the socialists, who identified the modern industrial structure with monopoly and advocated for its social control a comprehensive program of public ownership.

2. Between 1898 and 1904,239 corporate consolidations of national or regional signifi. cance, each capitalized for more than $\$ 1,000,000$ and together covering practically every important manufacturing industry, took place. Moody, THE Truth About tue Trusts 453-67 (1904). The second merger movement began in 1925, when 554 mining and manufacturing firms were merged, and ended in 1929, when 1,245 such firms were merged. Thorp, The Merger Movement, in The Structure of IndUSTRY, table 1, p. 233 (TNEC Monograph No. 27, 1941).

3. Joan Robinson, The Economics of Inperfect Coxpetition (1933), appeared in England about the same time. However much it differs from Chamberlin's theory in the details of its logic, it is an intellectual response to similar institutional developments and arrives at similar conclusions on the nature of pricing in markets of few sellers.

4. Chamberlin postulated an industrial structure of few sellers, a standardized product, and identical demand and cost curves known to the sellers. Chandmertin, The Tukony of Monopolistic Competition 30-31 (6th ed. 1948).

5. Burns, The Decline of Conpetttion cc. 11-12 (1936).

6. Fetter, Planning for Totalitarian Monopoly, 45 J. Pox. Econ. 95 (1937).

7. Nourse, Price Máking in a Democracy (1944). 
Other economists found solace in a new logic. The new logic drew its inspiration and designation from J. MI. Clark's paper before the American Economic Association in December 1939, "Toward a Concept of IVorkable Competition." $\mathrm{Clark}$ in pioneering this concept noted what other economists had observed-that the economists' models of pure and perfect competition were abstractions to which the realities of the business world do not conform -and he sought a general concept more useful in analyzing markets and evaluating their economic significance. Recognizing that actual market arrangements are intermediate between those of pure competition and monopoly, he sought to describe those which are workably competitive. In markets of workable competition such control as a seller may exert is slight, and under certain circumstances it may do more good than harm. In any event a market arrangement, to be workably competitive in Clark's terms, must be economically more advantageous to the general public than any practically attainable alternative. Other economists have busied themselves with the concept of workable competition, and it has become a part of the profession's stock-intrade. $^{9}$ As others have contributed to it the concept has acquired greater depth and breadth but not greater precision. What it is rapidly coming to mean is not very different from what economists of an earlier period meant by the less pretentious term "competition." According to the modernized concept an industry is effectively or workably competitive if market forces-i.e., the total influence of independent decisions by buyers and sellers regardless of their number-provide the drive for technological innovation, the allocation of resources, the organization of production, and the distribution of income. ${ }^{10}$

The architects of workable competition, despite the vagueness of the concept, have laid down certain criteria by which it may be gauged. Most would agree that in determining the effectiveness or workability of competition in any particular industry one should examine its structure, the conduct of firms within it, and the performance of the firms and of the industry as a whole. Conclusions based on any one of these criteria may be ill-founded, lut together all three criteria may form a logical basis for judgment.

8. 30 Axr. Econ. Rev. 241 (1940).

9. Edwards, Matntaining Cosipetition 9-10 (1949); Adelman, supro note 1; Bain, Workable Competition in Oligopoly, 40 Aar. Ecow. REv. (Papars and Procecdings of the Anerican Economic Association) 35 (Supp. 1950); Markham, An Alicnative Approach to the Concept of Workable Competition, 40 Arr. Ecos. Rev. 349 (1950); Mrason, JIcthods of Developing a Proper Control of Big Business, 18 ACAD. PoL. Scr. Psoc. 40 (1939); Mason, The Current Status of the Monopoly Problem in the Ustitcd States, 62 Husv. L. Rev. 1265 (1949); Stigler, The Extent and Bases of Monopoly, 32 Asr. Ecos. Rev. (No. 2 Supp., Pt. 2) 2-3 (1.942) ; Wilcox, Cospetition And Mionopoly in Assenscis: Ixdustns (TNEC Mionograph No. 21, 1940).

10. Contemporary critics of the theory of "pure" competition criticize that theorywhich is largely of their own invention, they having supplied the qualifying "pure" and the concept it describes-on the grounds that it is concerned with equilibrium in a static economy and that it ignores the nature of, and the forces providing, technological innovation. I do not find this a shortcoming of the leading economists of the late nineteenth century, Marshall and Clark, for example. 


\section{The Structure of an Industry}

By an industry's structure economists refer to an industry's make-up, how it is put together, how its parts are interrelated. How many firms are in it? What is their relative size? Does a single firm dominate it? How difficult is the movement of resources into and out of it? What are the limits of its market? How sharply is it differentiated from other "industries" producing rival products readily substitutable for the product it makes? Economists believe that the answers to such questions will throw some light on the effectiveness or workability of competition.

Where an industry consists of only two or a few firms each producing a homogeneous product and operating under identical cost conditions, each fully informed of market conditions and each taking account of the indirect as well as the direct consequences of its decisions, Chamberlin argued that the firms will behave like monopolists. ${ }^{11}$ That is to say, they will produce the same amount as a single firm would produce and sell it at the same price. To insure monopoly behavior the firms need not conspire, but the results will be the same as though they had conspired. As the number of firms increases, the likelihood of their behaving like monopolists decreases. Eventually the number of sellers may become so large that some one (and hence all) will conclude that he need not take account of the indirect consequences of his decisions. That is to say, he will behave like a competitor and the result will be pure competition. Chamberlin recognized that lack of knowledge about the market or differing interpretations of it might lead to non-monopolistic behavior, and he was not unaware of the fact that no business situation is likely to conform exactly to his model.

While Chamberlin's analysis may have convinced some economists that a market of few sellers is less likely to be workably competitive than a market of more numerous sellers, it has certainly not convinced all. Adelman, for example, regards competition as compatible with "many small firms . . . with a few large ones ... and with large and small ones together."12 Adelman no doubt expresses the views of many other economists. Clark recognized that potential competition may afford an effective check on the temptation of oligopolists to exploit their markets. ${ }^{13}$ And in any event economists generally recognize that the absence of a large number of firms is not in all cases a useful criterion, for in many industries the optimum scale of production is so large that maximum efficiency decrees a small number of sellers.

When the market for a product is ill-defined, so that the product faces competition from products so slightly differentiated that they meet almost identical needs, producers of similar products may serve as an adequate check on each other in what is loosely regarded as an industry. Whether they do in fact so check each other will depend on what economists call the cross-elasticity of demand. Cross-elasticity reflects the extent to which price changes in one

11. Chamberlin, op. cit. supra note 4, at 49-50.

12. Adelman, Effective Competition and the Antitrust Laws, 61 HARv. L. Rev. 1289, 1303 (1948).

13. Clark, supra note 8 , at 246-47. 
product affect the amount of another product that buyers will buy. Where the cross-elasticity of demand for rival products is great, a decline in the price of one decreases the sale of the other and may lead to a decline in its price. The production of numerous similar products with a high cross-elasticity of demand may perform about the same economic function as does the existence of numerous sellers of the same product. Thus rival products may contribute to the workability of competition, but they do not guarantee it.

\section{Conduct}

How firms behave may be more important than structure in determining the effectiveness of competition, but behavior is a matter about which generalization is hazardous. The vigor of competitive rivalry may depend as much on the character and aspirations of the executive officers of a firm as on the industry's structure. Not all businessmen are dedicated to the principle of maximizing earnings. Some may' aspire to earn only a "reasonable" profit; when they do, other firms may be forced to accept a similar goal. Business analysts may differ in their opinions as to the effects of price cuts on output and costs, and they may make different value judgments. Even though firms may eschew price competition, they do not necessarily forego competitive rivalry. They may try to improve organizational efficiency and the productive process, thus reducing costs and perhaps eventually prices as well. Or they may improve their product or the services supplied with it, thus offering better goods for the same money.

But in oligopolistic industries business conduct is not necessarily of a salutary character, and structure itself may shape conduct. Such conduct may include the sort of predatory practices that the old Standard Oil Trust made notorious-secret rebating, local price discrimination, espionage, operation of bogus independents, and the like-but it also includes business practices that are regarded as sound and ethical by the firms that pursue them. Price leadership and basing point pricing are illustrations. Although the Chamberlinian theory of oligopoly points to the conclusion that conspiracy among few sellers may be unnecessary to insure noncompetitive pricing, few economists would rely on the theory alone in reaching a conclusion about business behavior. Most economists would concede, however, that fewness of sellers may encourage the development and use of business practices-types of business conduct-not consistent with effective competition.

Conduct as the term is here used may refer to neither predatory nor ordinary business practices, but to the strategy resorted to by a firm in seeking to protect an advantage it already has. Such strategy or conduct aims at the protection of a trade secret, a patent, or a superior source of supply, or at blocking entrance to an industry or a market. Strategy is the weapon of a firm operating in an imperfectly competitive market, but resort to strategy is not necessarily inconsistent with workable competition. As suggested, it may lead to the improvement of processes and products. It may mean better goods at lower prices. On the other hand, conduct or strategy that on its face reflects 
a vigorous rivalry may serve to isolate a producer from the impact of competition long enough to prevent its being workable.

In short, the conduct of firms alone may be no more satisfactory for determining the effectiveness of competition than structure alone. Just as structure may reflect itself in conduct, so conduct may reflect itself in performance.

\section{Performance}

By performance economists mean the effectiveness or efficiency with which, from the economic point of view, a firm or industry acquits itself. Is it dy namic or lethargic? Is it quick to introduce new methods and improve its product? What is the course of its prices? Do they reflect reductions in cost which are rapidly passed on to consumers? What is its rate of profit? Is "progress" its "most important product"? Does it make "better things for" better living" at prices within the reach of those who desire them? In measuring performance, as in evaluating conduct, an economist must be careftul of his conclusions. A monopolist may be lethargic or dynamic. A mature industry may be highly competitive but not progressive. A young industry may display remarkable vitality even though few firms occupy it. Its rate of return may merely express the rapid expansion of demand for its products. Contrariwise, it may reflect monopoly elements.

While no one of these criteria-structure, conduct, performance-is wholly satisfactory, many economists believe that together they may afford a useful guide in determining the effectiveness of competition within an industry. Of course guideposts are no better than the wayfarer's interpretation of them. Nevertheless a belief in their dependability led the Secretary of Commerce's Business Advisory Council and others to propose workable or effective competition under a rule of reason as a standard of legality in antitrust cases. ${ }^{14}$

\section{The Rule of Reason}

The proposals for modifying the antitrust statutes to require that they be interpreted and administered in accordance with "the rule of reason" justify

14. U.S. Dep't of Conmerce, Effective Competition: A Report to the Secretaily of Commerce by His Business Advisony Council (1952). Some students of antitrust have a different notion of the concept of workable competition from that expounded above. Oppenheim, Federal Antitrust Legislation: Guideposts to a Revised National Autitrust Policy, $50 \mathrm{MrcH}$. L. Rev. 1139, 1160 (1952), seems to imply that the workability of any particular industrial arrangement should be judged not only by its effect on competition but also by its effect on public welfare. He says: "In particular factual situations, evidence of legal, economic, and social justifications [should] ... be weighed under close judicial scrutiny to arrive at a determination of whether the restrictions are reasonable or unreasonable when measured against the effects upon competition." I understand this to mean that arrangements may be economically and socially justifiable even though they restrict competition, and if they are, the restriction should be regarded as reasonable. Smith, supra note 1, at 419, is equally obscure. He says: "Public policy should be in favor of such joint or group activities in so far as they advance tendencies toward more and better goods and services for more people in proportion to human efforts. ..." 
reconsideration of the derivation of the principle, its use at common law, the intent of Congress about it, and the courts' interpretation and application of it.

The principle is old. As applied to restraints of trade it developed in common law litigation growing out of private contracts. There the term "restraint of trade" had a technical meaning. ${ }^{15}$ It was used to characterize agreements not to compete between buyers and sellers of property, partners in a joint enterprise, apprentices and masters, and the like. For example, a buyer of a business wished to protect himself against the seller's future competition, or a seller of part of a business wished to protect the part he retained from the buyer's new competition. In consideration of the sale the buyer or the seller agreed not to compete in such a way as to detract from the value of the property retained or sold. Such contracts involved a restraint of trade. They also involved a restriction on competition, ${ }^{10}$ but neither English nor American legislatures oulawed them by statute. Contracts in restraint of trade first came before the courts only when one of the parties violated the contract. When the injured party resorted to litigation, the courts had to decide whether the contract was enforceable. In the early history of such contracts the English courts held that all of them were void because contrary to the public interest in two ways: they deprived an individual of a means of livelihood, and they deprived the public of his talents. ${ }^{17}$

But as trade and industry expanded in England and the obstacles to entry became less formidable; as the customs and laws governing British economic life, especially the laws of apprenticeship, were relaxed; as workmen moved more freely from one occupation to another; as the opportunities for contractual employment expanded; as freedom under contract replaced security based on status; and as the means of communication and transportation improved and markets broadened, the courts modified the common law by distinguishing between reasonable and unreasonable restraints on trade. ${ }^{18}$ In passing

15. For a somewhat similar view of the law on restraint of trade and of the development of the rule of reason, see Watrins, Industrial Coumbinations asid Public Policy 224-27 (1927); Handler, Resiraint of Trade, 13 Excrc. Soc Scr. 339-41 (1934).

16. They have no significance in a purely competitive market. No wheat farmer in selling a farm ever agrees as part of the bargain that he will not compete with the purchaser in raising and selling wheat. Contracts to "restrain trade" have meaning only where products are differentiated, sellers are few, or special skills or trade secrets are involved.

17. Apparentily the earliest recorded case of a contract in restraint of trade is Dyer's Case, Y.B., 2 Hen. 5, f. 5, p1. 26 (1415), in which the court not only refused to enforce a bond conditioned on the defendant's not practising his trade as a dyer in the plaintiff's town for six months but threatened: "[A]nd by God, if the plaintiff were here he should go to prison till he had paid a fine to the king." In Colgate v. Bacheler, Cro. Eliz. 872, 78 Eng. Rep. 1097 (K.B. 1601), the defendant's bond to pay $£ 20$ if he should use the trade of a haberdasher in certain cities was held void: "[I]t was resolved by the Court, that this condition is against law, to prohibit or restrain any to use a lawiul trade at any time, or at any place; for as well as he may restrain him for one time or one place, he may restrain him for longer times and more places, which is against the benefit of the commonwealth; for being freemen, it is free for them to exercise their trade in any place."

18. A contract restraining a joiner from practising his trade for a certain time (twentyone years) and in a certain place (the city of London) was upheld early in the seventeenth 
judgment on the reasonableness of restrictive contracts, they re-examined the nature of the transaction from the two points of view from which they had originally condemned them: the protection of the parties and the protection of the public. ${ }^{19}$ In determining whether the individuals had been injured they looked to the consideration binding the contract. In determining whether the public interest had been hurt they considered the seriousness of the restrictions on competition. Where there was a legal consideration for the restraint and the restrictions on competition were not regarded as oppressive, the courts came to uphold such contracts. ${ }^{20}$ This was the common law rule of reason, developed in the English courts and adopted in America. ${ }^{21}$

century. Rogers v. Parrey, 2 Bulst. 136, 80 Eng. Rep. 1012 (K.B. 1614). Broad v. Jollyfe, Cro. Jac. 596, 79 Eng. Rep. 509 (K.B. 1621), held that "for a valuable consideration, and voluntary, one may agree that he will not use his trade." But Mitchel v. Reynolds, 1 P. Wms. 181, 24 Eng. Rep. 347 (Ch. 1711), is the leading case on testing the validity of a restraint of trade by its reasonableness. The seller of a bakery who had given his bond for $£ 50$ not to practise his trade within the parish for five years resumed his trade and defended himself against the buyer's action for debt on the ground that the restraint was void. It was resolved by the court: "And we are all of opinion, that a special consideration being set forth in the condition, which shews it was reasonable for the parties to enter into it, the same is good...." The court also distinguished between general restraints "not to excrcise a trade throughout the kingdom," which were "of no benefit to either party, and only oppressive," and those "limited to a particular place," which were good. Id. at 182, 24 Eny. Rep. at 348.

19. Mitchel v. Reynolds, 1 P. Wms. 181, 190, 24 Eng. Rep. 347, 350 (Ch. 1711). Chief Justice Parker pointed out another danger in restrictive contracts: "the great abuses these voluntary restraints are liable to; as for instance, from corporations, who are perpetually labouring for exclusive advantages in trade, and to reduce it into as few hands as possible...." Ibid.

20. Some courts in upholding contracts imposing partial restraints on trade declarcel that only a partial restraint supported by a consideration which the court found adequate was valid. Homer v. Ashford, 3 Bing. 322, 327, 130 Eng. Rep. 537, 539 (C.P. 1825). Others said that the court need not weigh the reasonableness of the consideration so long as it was a legal one. Hitchcock v. Coker, 6 Ad. \& E. 438, 112 Eng. Rep. 167 (Ex. 1837). In 1837 the Exchequer Chamber upheld a general restraint (a carrier's agreement not to engage in his trade but to become an assistant to the defendants for the rest of his life), saying that a general restraint is good if made on sufficient consideration "and the public gain some advantage." Wallis v. Day, 2 M. \& W. 273, 281, 150 Eng. Rep. 759, 762 (Ex. 1837). Sometimes an unreasonably extensive restraint was held invalid while the reasonable portions of the same contract were upheld. Mallan v. May, 11 M. \& W. 653, 152 Eng. Rep. 967 (Ex. 1843) (dentist's agreement not to practise in London held good, but his agreement not to practise in any towns or places in England or Scotland where plaintiffs had practised, bad). In 1869 an agreement not to engage in the leather cloth business anywhere in Europe was upheld, the court saying that public policy enables a man "to enter into any stipulation however restrictive it is, provided that restriction in the judgment of the Court is not unreasonable, having regard to the subject matter of the contract." Leather Cloth Co. v. Lorsont, L.R. 9 Eq. 345, 354 (1869). And in Rousillon v. Rousillon, 14 Ch.D. 351 (1880), the court upheld a champagne salesman's general contract not to deal in champagne for ten years, saying that the invalidity of all general restraints of trade had never been the law of England.

21. E.g., Pike v. Thomas, 7 Ky. (4 Bibb) 486 (1817) ; Alger v. Thacher, 36 Mass. (19 
In evaluating the significance of this development it is important to keep in mind that the contracts whose reasonableness was initially in question were ancillary to transactions whose legality was not in dispute. During the latter part of the nineteenth century rival businessmen with increasing frequency contracted to restrict or eliminate competition among themselves. These arrangements were not incidental to contracts whose legality was beyond question. They were not designed to protect an individual in purchasing property or teaching a trade; they were aimed at market control. Their object was to lessen the severity of competition among business rivals or to monopolize markets. When injured parties brought suit against offenders who violated such contracts, the courts, confronted with a different kind of restraint on trade, sought refuge in the old doctrine.22 But in resorting to the rule of reason they did not always apply it in the same way.

Courts and commentators have disagreed about the way the common law rule of reason was applied to contracts whose purpose was market control. Judge Taft (later Chief Justice), in his review of the common law on restraint of trade in the Addyston Pipe and Steel Company case, ${ }^{23}$ concluded that the courts had generally held void all contracts having the sole object of restraining competition. Courts that had held otherwise, he contended, by assuming "the power to say ... how much restraint of competition is in the public interest, and how much is not" had "set sail on a sea of doubt.". Five years earlier Judge Sanborn, in deciding the Trans-MLissouri Frcight Association

Pick.) 51 (1837) ; Hubbard v. Miller, 27 Mfich. 15, $19-20$ (1873). In 1873 the Supreme Court upheld a buyer's contract not to use a certain steamer in California waters or on the Columbia River and its tributaries for ten years, saying: "In order that it may not be unreasonable, the restraint imposed must not be larger than is required for the necessary protection of the party with whom the contract is made." Oregon Steam Navigation Co. v. Winsor, 87 U.S. (20 Wall.) 64, 67 (1873). And in Diamond MFatch Co. v. Roeber, 105 N.Y. 473, 482, 13 N.E. 419 (1887), the court upheld a ninety-nine year contract not to manufacture or sell friction matches in the United States except in Nevads and Mrontans, saying: "If [a man's] . . . business extends over a continent, does public policy forbid his accompanying the sale with a stipulation for restraint co-extensive with the business which he sells?"

22. While ostensibly applying the principles of Mitchel v. Reynolds, 1 P. Wms. 181, 24 Eng. Rep. 347 (Ch. 1711), or other ancillary contract cases, some English and American courts sustained contracts designed only to divide territories, raise prices, control markets, or prevent competition. Wickens v. Evans, 3 Y. \& J. 318, 148 Eng. Rep. 1201 (Ex. 1829) (agreement between three competing trunk and box manufacturers to assign markets in England and Wales, not to pay in Oxford more than 6d. or \&d. for any tea chest, and to meet for mutual assistance if outside competition arose); Collins v. Lock, 4 App. Cas. 674 (1879) (agreement by four stevedoring firms to divide the business at the port of Mfelbourrie); Kellogg v. Larkin, 3 Pin. 123 (Wis. 1851) (an exclusive dealing contract between a grain dealer and a warehouseman, one of a series by which grain dealers vere seeking full control of the Milwaukee wheat market) ; Leslie v. Lorillard, 110 N.Y. 519, 18 N.E. 363 (1888) (steamship corporation's contract to pay another not to compete).

23. United States v. Addyston Pipe \& Steel Co., 85 Fed. 271 (6th Cir. 1898), modificd and aff'd, 175 U.S. 211 (1899).

24. Id. at 85 Fed. 271,284 (6th Cir. 1898). 
case in the district court, ${ }^{25}$ had reviewed the common law and reached at contrary conclusion. He found that at common law only pooling contracts among competing common carriers, or contracts or combinations to restrict or monopolize supply or to raise prices or pool profits among producers or dealers in "staple commodities of prime necessity to the people," were illegal restraints

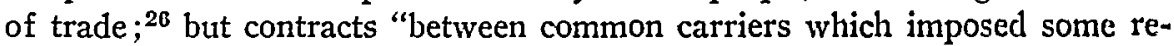
strictions upon competition have been frequently sustained by our highest courts, and the rule has been often applied that the test of their validity was not the existence, but the reasonableness, of the restriction imposed."27 Handler, after reviewing the cases and the commentators, recognizes three trends in the authorities before 1890: (1) The prevailing view was that contracts among business rivals that restrained or eliminated competition were unlawful per se. (2) Some jurisdictions, finding the contracts before them so limited in scope as to be ineffective, reached the somewhat anomalous conclusion that they were therefore enforceable. (3) Other courts, seemingly lacking faith in competition as a regulator of economic activity, found price-fixing agreements valid when the prices were designed not to exploit the public but to rectify "intolerable industrial conditions." 28 Thorelli ${ }^{20}$ suggests that the conflicts in common law decisions may have been due in part to a divergence in English and American public policy toward restrictive arrangements, which developed in the nineteenth century:

"In the course of the 19th century the doctrine of restraint of trade was extended to cover, ultimately, restrictions on trade in general. It is in this broad sense that it has been of such great significance in the development of American antimonopoly policies. Whereas the extension of the restraint of trade concept in England marked the beginning of a

25. United States v. Trans-Missouri Freight Ass'n, 58 Fed. 58 (8th Cir. 1893), rev'd, 166 U.S. 290 (1897).

26. Id. at 58 Fed. 58,69 (8th Cir. 1893).

27. Id. at 74. Judge Sanborn said that the reason contracts of the kinds he described were held void was that their "main purpose . . . is to suppress, not simply to regulate, competition. ..." Id. at 69. Peppin, Price-Fixing Agreements under the Sherman AntiTrust Law, 28 CALIF. L. REv. 297, 667 (1940), supports Judge Sanborn's interpretation. His thesis is that the common law always upheld agreements directly affecting prices without directly fixing them, and that beginning early in the nineteenth century nonancillary agreements eliminating price and all other competition between the parties were upheld if reasonable. He says that while the early cases invalidating price-fixing agreements did not refer to them as restraints of trade, "it would seem clear that such was the real objection...." Id. at 324 .

28. Handler, A Study of the Construction and Enforcenent of the Federal Antitrust Laws 4-5 (TNEC Monograph No. 38, 1941).

29. Thorelli, The Federal Antitrust Policy (1.955), came off the press as this article was being completed. Although written by a Swedish scholar, this work gives the most comprehensive, detailed, and penetrating analysis yet to appear of the legal, economic, social, and political background of the Sherman Act and its administration through 1903. Of the significance of the common law he says: "It was the belief, common in the 17 th and quite general in the 18th and 19th centuries, that the common lan' 'alatays' had bien opposed to monopolies, or even actively favored competition, rather than an inherchlly antimonopolistic quality in its relevant doctrines that proved important." Id. at 51. 
continuous relaxation of public policy, American courts moulded the broadened doctrine into a useful, if imperfect, general antimonopoly instrument. And whereas the 'rule of reason,' adopted from the 'narrow' restraint of trade doctrine, was used to implement the gradual weakening of the extended doctrine in England, there was relatively little use of it in this new field in the United States."30

With the courts and the commentators thus in disagreement a layman may reasonably conclude that the common law on restrictions of competition was inconsistent and confused.

\section{The Sherman Act}

The Sherman Act, many commentators unwittingly imply, was designed to perpetuate this confusion. The record reads differently. To understand the purpose of the Sherman Act one must understand the temper of the times that gave it birth. The decade of the 1880's was the heyday of the trusts. The Standard Oil Trust, the Cottonseed Oil Trust, the Linseed Oil Trust, the National Lead Trust, the Whiskey Trust, the Sugar Trust were all of this era. The power of these great combines, and the predatory practices by which they achieved or perpetuated their power, greatly disturbed consumers who bought their products, businessmen who confronted them as rivals in the market, politicians elected to promote the public welfare, and students of industrial structure and business behavior. This anxiety was reflected in contemporary professional and popular literature ${ }^{31}$ and in political convention halls. Both the Democratic and the Republican parties in their 1SSS platforms scathingly condemned combinations that controlled markets and exploited consumers; ${ }^{32}$ and the Democrats, more specific than their political rivals, declared their faith in Adam Smith's "obvious and simple system of natural liberty"-or as they called it, "natural competition." 33

Senator Sherman, although he wrote not a word of the act that bears his name, ${ }^{34}$ appropriately has been regarded as its father. It is Senate Bill No. 1,

30. Id. at 52-53.

31. E.g., Barry, The Moloch of Monopoly, 7 The Forum 436 (18s9); Hudson, Moders Fetdalism, 144 The North American Review 277 (1887); Wood, The Bugbcar of Trusts, 5 The Forum 584 (1888); Editorial, Trusts and Confidences, 44 The Nation 380 (1887). In the professional journals appeared such articles as Gunton, The Economic and Social Aspects of Trusts, 3 PoL. Scr. Q. 385 (188S); Hadley, Prizate Monopolics and Psbblic Rights, 1 Q. J. Econ. 28 (18S6).

32. The Republicans declared their "opposition to all combinations of capital, organized in trusts or otherwise, to control arbitrarily the condition of trade among our citizens; and ... all schemes to oppress the people by undue charges." McKEE, The Natro:sat Conventions and Platrorars of Ail Political Parties 241. (1906). The Democrats asserted: "[T] he interests of the people are betrayed when, by unnecessary taisation, trusts and combinations are permitted to exist, which, while unduly enriching the few that combine, rob the body of our citizens by depriving them of the benefits of natural competition." Id. at 235 .

33. Ibid.

34. See Walker, Histogy of the Sheraran Law 2 (1910) ; Hornblower, "Antilrust" Legislation and Litigation, 11 Coluas. L. Rev. 701 (1911). See also Berasar, Lacon Axd 
introduced by Sherman in the first session of the Fifty-first Congress on December 4, 1889, and the congressional debates on it, that reveal what Senator Sherman and Congress were aiming at. Sherman apparently wanted Congress to go as far as it could in outlawing arrangements that restricted competition. But a ban by Congress on contracts to restrain competition had to be brought within its constitutional power to regulate commerce among the states and with foreign countries. Section 1 of the Sherman bill indicated its twofold purpose: to outlaw as far as it could all arrangements that limited competition and at the same time to keep the ban within the jurisdiction of Congress. ${ }^{35}$

Two substitute bills offered in the Senate grappled with these twin problems of comprehensiveness and constitutionality. ${ }^{36}$ The debates on these several measures reflected continuing doubt on both scores, and Senator Sherman made it clear that he did not believe that the proposed bills presented a new principle of law, but rather that they banned by federal statute what the states had banned by statute or at common law. ${ }^{37}$ Sherman's statements on this issue may raise some question about his knowleclge of the common law, ${ }^{\text {d8 }}$ but they raise no doubt about his intentions and in no way restrict the meaning

The Sherran Act c. 3 (1930) ; McLaughlin, The Federal Antitrust Laws of tile: United States 7, 18-25 (1933); and especially Thoreill, The Federal Antitrust PoLICY 210-14 (1955).

35. Section 1 provided:

"That all arrangements, contracts, agreements, trusts, or combinations between persons or corporations made with a view or which tend to prevent full and free competition in the importation, transportation, or sale of articles imported into the United States, or in the production, manufacture, or sale of articles of domestic growth or production, or domestic raw material that competes with any similar article upon which a duty is levied by the United States, or which shall be transported from one State or Territory to another, ... are hereby declared to be against public policy, unlawful, and void."

21 Cong. Rec. 1765 (1890). The antitrust bills introduced in the 50th Congress on August 14, 1888, by Senator Sherman, S. 3445, 19 CoNG. Rec. 7513, and Senator Reagan, S. 3440, 19 Cong. REc. 7512, had shown similar purposes. Despite the circumlocutions of S. 1, 51st Cong., 1st Sess. (1889), Senator George of Mississippi challenged its constitutionality on the ground, among others, that it proposed to regulate manufacture and production within a state. 21. CoNG. Rec. 1768 (1890).

36. A substitute bill presented by the Senate Finance Committce on March 21, 1890, limited its scope to contracts, etc., between parties in different states or with foreigners, but banned all arrangements made with " $\mathrm{a}$ view or which tend to prevent full and free competition." 21 CoNG. REc. 2455 (1890). Senator Reagan of Texas offered a substitute for the substitute which defined trusts comprehensively, including any arrangement that prevented competition or restricted trade. 21 id. at 2455-56.

37. "It does not announce a new principle of law, but applies old and well recognized principles of the common law to the complicated jurisdiction of our State and Federal Government. Similar contracts in any State in the Union are now, by common or statute law, null and void." 21 CoNg. Rec. 2456 (1890). Sherman reviewed at length a number of recent state cases holding combinations to prevent competition illegal and of no effect and said he might add "innumerable" others. 21 id. at 2458-59.

38. See text at note 28 supra for Handler's classification of common law principles; cf. Peppin's views, note 27 supra. 
of the language by which he proposed to outlaw arrangements that substituted collusion for competition in the market place. ${ }^{39}$

On March 27, 1890, the Senate referred the antitrust bill to the Committee on the Judiciary. ${ }^{40}$ Instructed to report within twenty days, the committee did so within a week. It offered as a substitute for the original Sherman bill a bill which passed the Senate with only one dissenting vote, ${ }^{21}$ which passed the House with no dissent, ${ }^{42}$ and which with President Harrison's signature on the second of July became the Sherman Act. ${ }^{43}$ The language of the Sherman

39. Senator Sherman stated to the Senate: "Mrr. President, the object of this bill, as shown by the title, is to declare unlawful trusts and combinations in restraint of trade and production.' It declares that certain contracts are against public policy, null and roid." 21 Cong. Rec. 2456 (1890). Sherman also described his bill as "a remedial statute to enforce by civil process in the courts of the United States the common law against monopolies." $21 i d$. at 2461. Thorelli, The Federal Axtrtrust Polict 228 (1955), concludes that "there is ample evidence that not only the bills reported by Sherman in the 5lst Congress but also the bill finally passed were intended by their sponsors primarily to be iederal codifications of the common law of England and the several states." But it is apparently the common law as applied by courts to hold unlawful contracts to restrict competition and block the operation of market forces that Thorelli has in mind, for he asserts and reiterates, "Congress believed in competition." Id. at 226. "There can be no doubt," he says, "that Sherman's views were typical in the sense that the vast majority of congressmen were sincere proponents of a private enterprise system founded on the principle of 'full and free competition.'" Ibid.

40. 21 CoNG. Rec. 2731. (1S90).

41. 21 id. at 3153 .

42. $21 \mathrm{id}$. at 6314 . Despite the unanimity with which Congress acted, sume scholars contend that it was not seriously concerned with the monopoly problem. CLARK, TrE Federal Trust Policy 30 (1931), states that the "brief consideration of the bill in the Senate and the cavalier handling of it in the House are cogent pruofs that the legislators themselves were not greatly aroused by any 'trust peril." "FalNsud \& Gornon, GoversMIENT AND THE Axrertcan EConosry 450 (1941), say: "While hindsight justly views it as one of the most important measures ever passed by Congress, it is doubtiul if any member of the 51st Congress so thought of it." An examination of the Cungressional Recurd creates a different impression. The persistence with which the legislaturs considered it and the language they used in discussing it indicate grave concern about the trust prublem. In the first session of the 50th Congress, Senators introduced four bills designed to deal with the trust problem and in the House twelve similar bills were introduced. 19 Co:s. REc. passin (1888). Senator Sherman's bill, S. 3445, was debated on three occasiuns in the second session of the 50th Congress. 20 CoNg. REc. 1120, 1167, 1457-62 (1859). In the first session of the 51st Congress, Senators Shernan, George, and Reagan introduced three antitrust bills (including S. 1, later rewritten into the Sherman Act); Senator Turpie introduced a resolution to include in the proposed penal enactments against trusts a provision for the seizure of "trust goods," 21 CoNG. REC. 125 (1890); and Senstor George introduced a joint resolution to amend the Constitution to enable Congress to prohibit combinations in restraint of trade, S.R. 67, 51st Cong., 1st Sess. (1890). Its counterpart, H. REs. 30, 51st Cong., 1st Sess. (1890), was introduced in the House of Representatives, where members also introduced eighteen bills to outlaw trusts as variously defined or trusts in specific industries, such as cattle. 21 CoxG. Rec passim (1890). In debating these measures many Congressmen expressed with fervor their condemnatiun ui monopolies and trusts.

43. 26 Stat. 209 (1890), as amended, 50 Stat. 693 (1937), 15 U.S.C. 11 (1952). 
Act was wholly different from the langauge of the initial Sherman bill, but nothing in the Congressional Record indicates that its purpose was not the same. ${ }^{44}$ It apparently aimed, as had its predecessors, to go as far as the jurisdiction of Congress permitted in banning every restriction on competition.45 As Congressman Stewart of Vermont put it, "The provisions of this trust bill are just as broad, sweeping, and explicit as the English language can make them to express the power of Congress over this subject under the Constitution of the United States."48 The new language eliminated all doubt about jurisdiction, but despite Mr. Stewart's characterization it started a debate about scope that has continued until today.

\section{The Rule of Reason and Monopoly}

The debate was precipitated in the Trans-Missouri Freight Association case, ${ }^{47}$ when Justice Peckham and a majority of the Supreme Court held that the language of the Sherman Act meant what it said-that the law banned every contract that restrained trade, regardless of form, and every conspiracy to achieve this end. Justice White and three other Justices dissented, and in doing so reviewed the common law rule of reason. ${ }^{48}$ Fourteen years later Chief Justice White, writing for a majority in the 1911 Standard Oil decision, con-

44. Senator Hoar explained the bill's purpose as follows:

"The complaint which has come from all parts and all classes of the country of these great monopolies, which are becoming not only in some cases an actual injury to the comfort of ordinary life, but are a menace to republican institutions themselves, has induced Congress to take the matter up. . . . Now, the Judiciary Committee has carefully and as thoroughly as it could agreed upon what we believe will be a very efficient measure, under which one long forward step will be taken in suppressing this evil. We have affirmed the old doctrine of the common law in regard to all interstate and international commercial transactions, and have clothed the United States courts with authority to enforce that doctrine by injunction."

21 Cong. Rec. 3146 (1890).

45. Section 1 outlaws "Every contract, combination in the form of trust or otherwise, or conspiracy, in restraint of trade or commerce among the several States, or with forcign nations"; and $\S 2$ makes guilty of a misdemeanor "Every person who shall monopolize, or attempt to monopolize, or combine or conspire with any other person or persons, to monopolize any part of the trade or commerce among the several States, or with forcign nations." (Emphasis supplied.) 26 Stat. 209 (1890), as amended, 50 Stat. 693 (1937), 15 U.S.C. \$ 1 (1952).

46. 21 CoNG. Rec. 6314 (1890).

47. United States v. Trans-Missouri Freight Ass'n, 166 U.S. 290 (1897). "When . . . the body of an act pronounces as illegal every contract or combination in restraint of tradc or commerce among the several States, etc., the plain and ordinary meaning of such lat1guage is not limited to that kind of contract alone which is in tinreasonable restraint of trade, but all contracts are included in such language, and no exception or limitation can be added without placing in the act that which has been omitted by Congress." II. at 328.

48. White noted the law's progression from Dyer's Case, Y.B., 2 Hen. 5, f. 5, pl. 26 (1415), through Mitchel v. Reynolds, 1 P. Wms. 181, 24 Eng. Rep. 347 (Ch. 1711), to Nordenfelt v. Maxim Nordenfelt Guns \& Ammunition Co., [1894] A.C. 535, in which the House of Lords ruled that the old distinction between partial and general restraint was an incorrect criterion and that the true test was whether, considering all the circumstances, 
cluded that Congress had not outlawed all contracts that restrained trade but only those that unreasonably restrained it $;{ }^{49}$ despite the fact that two years earlier, with the issue before it, Congress had refused to modify the statute, ${ }^{, 0}$ and despite the fact that White identified restraint of trade with restriction of competition, ${ }^{51}$ as Congress had done. Thus, recognizing that Congress intended to give a broad new meaning to the term "restraint of trade," White nevertheless read into it the rule of reason which had qualified the original common law use of the term.

If Congress had used "restraint of trade" in its narrow technical meaning as a contractual limitation on the right of a seller of property, a participant in a partnership, or an apprentice to exercise his trade, and if it had been guided by either common sense or precedent, it must certainly have distinguished between reasonable and unreasonable restraint. But seeking as it was to preserve a competitive society, Congress was under no obligation to make such a distinction. In truth, in outlawing every restriction on competition it did all that it could do but no more than was necessary to achieve its objective.

the contract was reasonable or unreasonable. "If reasonable, it was not a contract in restraint of trade, and if unreasonable, it was." United States v. Trans-Alissouri Freight Ass'n, 166 U.S. 290, 347 (1897).

49. Standard Oil Co. v. United States, 221 U.S. 1 (1911). White reasuned that (1) the context of the Sherman Act "manifests that [it] ... was drawn in the light of the existing practical conception of the law of restraint of trade," since it ignores the carly precise meaning of contracts in restraint of trade and includes under that term contracts or acts designed to monopolize as well; and (2) because many new forms of contract and combination were evolving from changing economic conditions, Congress "by an all-embracing enumeration" had sought "to make sure that no form of contract or combination by which an undue restraint of interstate or foreign commerce was brought about could save such restraint from condemnation. The statute under this view evidenced the intent not to restrain the right to make and enforce contracts, whether resulting from combination or otherwise, which did not unduly restrain interstate or foreign commerce, but to protect that commerce from being restrained by methods, whether old or new, which would constitute an interference that is an undue restraint." Id. at 59-60.

50. S. 6440, 60th Cong., 2d Sess. (1909), would have amended the Sherman Act to provide, among other things, that no prosecutions under its first six sections should be maintained for past offenses unless the contract or combination was in unreasonable restraint of trade. The Senate Committee on the Judiciary rejected this proposal, saying that to make "civil and criminal prosecution hinge on the question of reasonableness or unreasonableness ... destroys ... the provisions of the act as to crimimal prosecutions, and renders them nugatory, and opens the door wide to doubt and uncertainty as to civil prosecutions. ... The defense of reasonable restraint would be made in every ease and there would be as many different rules of reasonableness as cases, courts, and juries." $\mathrm{S}$. REP. No. 848, 60th Cong., 2d Sess. 9-11 (1909).

51. White described the purpose and nature of the law on restraint of trade as follows: "[T]he dread of enhancement of prices and of other wrongs which it was thought would flow from the undue limitation on competitive conditions caused by contracts or other acts of individuals or corporations, led, as a matter of public policy, to the prohibition or treating as illegal all contracts or acts which were unrcasonably reId. at 58 . strictive of competitive conditions...."

52. The first Sherman Act case before the Supreme Cuurt seemed to indicate that 
Many students of the law and economics of monopoly argue that the courts have been forced to adopt a rule of reason in applying the Sherman Act. If by this they mean that courts must exercise discretion and judgment, after considering all the relevant facts, in determining whether a contract restrains or promotes competition, ${ }^{53}$ they are right. If they mean that it is a proper judicial function to determine to what extent competition may be impaired by contract without harming the public interest, ${ }^{54} \mathrm{I}$ believe they are wrong. More important, they would impose on the courts, which must undertake the unavoidable task of determining whether a contract does in fact impair competition, the additional burden of determining whether contracts that impair competition do so unreasonably. To determine how much restriction on competition by private enterprise can be justified on economic grounds is an almost insuperable task, even for economists.

In the Standard Oil case it was important that Chief Justice White find an easy way to answer an insoluble problem. To cletermine whether the Standard

Congress had not done enough. The Court construed the statute as applicable only to combinations to monopolize interstate commerce, not to combinations within one state to monopolize the manufacture of a product sold in interstate commerce. United States v. E.C. Knight Co., 156 U.S. 1, 17 (1895). This drastic limitation of the law's scope, together with the Court's assertion that "Congress did not attempt ... to assert the powcr to deal with monopoly directly as such; or to limit and restrict the rights of corporations created by the States ... or to make criminal the acts of persons in the acquisition and control of property which the States of their residence or creation sanctioned," id. at 16 , apparently gave the Great Combination Movement approved legal status just as it was getting under way. Beginning with Northern Securities Co. v. United States, 193 U.S. 197 (1904), however, the Supreme Court receded from its narrow conception of Congress' power over interstate commerce.

53. Certain passages in the 1911 Standard Oil opinion read as if this is what Chief Justice White meant. In answering the Government's contention that the Sherman Act embraces every contract, etc., in restraint of trade and "imposes the plain duty of applying its prohibitions to every case within its literal language," White declared that this interpretation erred in assuming the matter to be decided, since judgment must be crecrisid to determine whether a particular act falls within the statutory classes and if it does whether its nature or effect makes it "a restraint of trade within the intendment of the act." Standard Oil Co. v. United States, 221 U.S. 1, 63 (1911). Oppenheim, Fedcral Antitrust Legislation: Guideposts to a Revised National Antitrust Policy, 50 Mrcu. L. REv. 1139, 1.176-77 (1952), at times seems to have a similar conception of the rule of reason. He says: "When all relevant economic and factual data are considered, the Rule of Reason enables a judgment to be made regarding the effects of any arrangement in resolving the question whether it promotes more competition than it restrains, or the reverse." At other times he seems to mean something quite different. See note 54 infra.

54. Oppenheim's most elaborate exposition of the significance of the rule of reason implies this. He would have proof of "a restrictive agreement alleged to be in violation of the antitrust laws" constitute a prima facie case of illegality which the respondent might answer by showing "justification within the allowable limits of the antitrust statutory standards," whereupon the court would "apply the Rule of Reason to the entire record"; that is, he would exercise discretion in evaluating the evidence "to arrive at a value julgment" which apparently could include toleration of "restrictions of joint conduct" "in in-" dividualized situations where there are overriding legal, economic and social justifications" for them. Oppenheim, supra note 53, at 1159, 1161. (Emphasis added.) 
Oil Company's officers and subsidiaries had combined or conspired to restrain trade, the Supreme Court looked to their motives. To determine motives the Court examined their conduct. As this discussion has indicated, an appraisal of conduct broadly conceived is not irrelevant to economic considerations, but it is not a substitute for them, particularly where conduct is judged primarily by ethical standards. But since the task which the Court had set itself was beyond its capacities, this standard was about the only one open to it. The Court found that Standard Oil had relentlessly absorbed its rivals or ruthlessly driven them out of business. In shipping oil it had obtained discriminatory rebates; in selling oil it had resorted to discriminatory pricing. In combatting rivals it had engaged in espionage; in selling petroleum products it had practiced deceit. ${ }^{55}$ The Court concluded that

"no disinterested mind can survey the period in question without being irresistibly driven to the conclusion that the very genius for commercial development and organization which it would seem was manifested from the beginning soon begot an intent and purpose to exclude others which was frequently manifested by acts and dealings wholly inconsistent with the theory that they were made with the single conception of advancing the development of business power by usual methods, but which on the contrary necessarily involved the intent to drive others from the field and to exclude them from their right to trade and thus accomplish the mastery which was the end in view."ש6

In applying the rule of reason in the American Tobacco case ${ }^{\text {si }}$ the Court again looked to motives, and to determine motives it examined conduct. In finding American Tobacco's behavior reprehensible the Court was even more explicit in making illegality synonymous with bad conduct. The Court reasoned that in view of "the undisputed facts ...., it remains only to determine whether they establish that the acts, contracts, agreements, combinations, etc.. which were assailed were of such an unusual and arongful character as to bring them within the prohibitions of the law."ss The Court found that they were. In truth it found an "ever-present manifestation ... of a conscious wrongdoing."59 Such were the primary grounds on which it concluded that the Standard Oil and American Tobacco Companies had violated the Sherman Act.

The 1911 American Tobacco and Standard Oil decisions are important not merely because of the importance of the particular industrial combinations involved but because the suits were initiated as a challenge to the most significant combination movement this country has ever experienced. Between 1898 and 1904 the great merger movement had transformed the structure of Ameri-

55. The Government's description of Standard Oil's allegedly unlaviul practices covered fifty-seven pages of the printed record. Standard Oil Co. v. United States, 221 U.S. 1, 42 (1911).

56. Id. at 76 .

57. United States v. American Tobacco Co., 221 U.S. 106 (1911).

58. Id. at 181. (Emphasis added.)

59. Id. at 182 . 
can industry. It had changed markets of many sellers into markets of few sellers and markets of few sellers into markets of fewer sellers. It had created few if any outright monopolies, but the changes it had wrought in the pattern of industry undoubtedly had affected market behavior.

Although the Supreme Court found that the Standard Oil and American Tobacco Companies had violated the Sherman Act and ordered their dissolution, the decisions reflected a judicial attitude friendly to industrial consolidation and a complacency towards market power not evidenced by the Congress that enacted the statute. The Court's enunciation of the rule of reason and its emphasis on intent and conduct laid the basis for a series of decisions that left undisturbed some of the greatest of the industrial combines. ${ }^{60}$ It is scarcely an exaggeration to say that it validated the new industrial structure.

The 1920 Steel case ${ }^{61}$ illustrates this generalization. Here was a suit to dissolve the greatest combination that had come out of the country's grentest combination movement. The United States Steel Corporation, American's first billion dollar concern, was a combination of combinations into the making of which some 180 independent firms had gone. But the Supreme Court in the Standard Oil and American Tobacco cases had by its rule of reason put stuch combinations beyond the reach of section 1 of the Sherman Act unless they had a long history of predatory practices showing a continuing intent to suppress competition. That left section 2, of course, as an instrument for striking down combinations that had monopolized their markets. But unfortunately monopoly is a no more precise term than restraint of trade. By the time the Steel case reached the courts the corporation's percentage of steel ingot output had shrunk from its original two-thirds to about one-half, and its relative share of the output of finished steel products had similarly lessened."2 The Supreme Court found the corporation large, but it concluded that the act did not condemn mere size. The corporation in the Court's judgment lacked monopoly power and had not abused such power as it may have had. ${ }^{\text {dy }}$

60. United States v. Winslow, 195 Fed. 578 (D. Mass. 1912), aff'd, 227 U.S. 202 (1913) (United Shoe Machinery Co.) ; United States v. American Can Co., 230 Fed. 859 (D. Md. 1916) ; United States v. United States Steel Corp., 251 U.S. 417 (1920); United States v. International Harvester Co., 274 U.S. 693 (1927).

61. United States v. United States Steel Corp., 251 U.S. 417 (1920).

62. U.S. Bureau of Corporations, Report ON THE StEel Industry, pt. I, 56 (1911).

63. Students of antitrust have commonly concluded from a study of the Amcrican Tobacco and Standard Oil cases and the 1920 Stecl case that the Stpreme Court distinguished between the existence of monopoly power and its abuse. The Attorney General's Committee on the antitrust laws rejected this conclusion. In its brief analysis of the Stecl case it found: "Technically ... the decision does not depend upon the so-called 'abuse' theory of Section 2." Report of the AtToRney General's National CoMmittee to Study the Antitrust Laws 50-51 (1955). But the dissenters in the Stecl case, fresh from their contact and discussions with the majority, thought differently. Justice Day said: "That the exercise of the power may be withheld, or exerted with forbearing benevolence, does not place such combinations beyond the authority of the statute which was intended to prohibit their formation. ..." United States v. United States Steel Corp., 251 U.S. 417, 464 (1920). Did the dissenters misconstrue the majority opinion? If in rejecting 
The extent to which this interpretation emasculated the Sherman Act as an instrument for preserving a competitive industrial structure in the American economy is, I believe, not generally understood. As previously indicated, the Great Combination Movement had created few if any complete monopolies, but it had changed greatly the pattern of industry by reducing the number of sellers in many national markets. In so doing it created the modern problem of oligopoly, where structure may influence conduct and conduct may influence performance. But unless their conduct is predatory, combinations falling short of monopoly under the rule of reason as originally enunciated are beyond the statute's reach. 64

The majority of the Attorney General's Antitrust Committee apparently failed to see this significance in the Court's decision in the Stcel case, or having seen it were silent. The Supreme Court dissenters in the case were more discerning. Unequipped with the modern tools of economic analysis and unfamiliar with professional jargon, the minority of the Court made a direct and uncomplicated, though certainly over-simplified, finding that the Steel Corporation, "fortified and equipped," as it was, "could if it saw fit dominate the trade and control competition. ...." So Some members of the Attorney General's Committee were equally discerning. They pointed out, as the dissenting opinion had done, that "it was erroneous in a case dealing with a combination or conspiracy which suppressed free competition, to require 'complete monopolization.' "'56 I believe they are correct.

\section{Later Decisions Disturb Business Leaders}

But it is not against applications of the rule of reason that the contemporary advocates of change have complained. Clearly big business would have much to gain by a return to the rule of reason as applied in the cases heretofure considered. Certain later decisions disturb them. They allege that big business as such is now under attack. The implications of the 1945 and 1950 decisions in the Aluminum case, ${ }^{67}$ and the minority opinion in the Columbia Stecl case, ${ }^{68}$ are their chief source of worry.

In the 1945 Aluminum opinion the Court of Appeals for the Second Circuit, sitting as a court of final review, was concerned primarily with the meaning

the nonexercise of market power as an answer to $\$ 2$ charges they were only lnoching down a straw man they had set up, Judge Hand in United States v. Aluminum Co. of America, 148 F.2d 416 (2d Cir. 1945), was doing the same thing twenty-five years later.

64. The Supreme Court's decision in American Tobacco Co. v. United States, 328 U.S. 781 (1946), of course condemned conspiracy among oligopolists and recognized that circumstantial evidence might be adequate to convict; but this was a criminal case and left the structure of the industry undisturbed.

65. United States v. United States Steel Corp., 251 U.S. 417, 464 (1920).

66. Report of the Attorney General's National Cosarittee to Study tue A:itiTRUST IAAWS 51 (1955).

67. United States v. Aluminum Co. of America, 148 F.2d 416 (2d Cir. 1945), newv petitions considered, 91 F. Supp. 333 (S.D.N.Y. 1950).

68. United States v. Columbia Steel Co., 334 U.S. 495, 534 (1948). 
and application of section 2 of the Sherman Act. The specific questions it posed were: (1) Did the Aluminum Company of America have a monopoly of the manufacture and sale of aluminum ingots? (2) If it did, had it violated the Sherman Act in obtaining it? In answering the first question Judge Learned Hand, speaking for the court, adopted an economic criterion. He found that for the five years 1934-1938 inclusive Alcoa had supplied over ninety per cent of the virgin aluminum bought by domestic consumers in ingots or fabricated products, and he ruled that this percentage "is enough to constitute a monopoly." 69 In rejecting the lower court's finding that between 1929 and 1938 Alcoa had controlled only thirty-three per cent of the domestic market-which the lower court had delineated as including secondary aluminum ${ }^{70}$ but not Alcoa's fabricated products-Judge Hand acknowledged that control of so small a percentage certainly did not constitute monopoly; and he said that control of sixty-four per cent (the proportion of Alcon's total production, including the aluminum it fabricated, to total secondary and imported virgin aluminum) was "doubtful."71

Having determined that Alcoa had a monopoly of the domestic market in aluminum ingots, the court turned to the second question: Had Alcoa violated the Sherman Act in achieving monopoly? To establish this, the court stated, it is unnecessary to show bad conduct or specific intent. A monopolist is not a sleepwalker $;^{72}$ it knows where it is going. In so reasoning the court discarded intent as a test of illegality where monopoly power has been achieved ${ }^{73}$ and held that Alcoa's having acquired monopoly was enough to condemn it, unless perhaps monopoly has been thrust upon it. Thus the court recognized that not all monopolies fall within the meaning of the statute. Apparently if the optimum size of a firm precludes competition, a firm that becomes a monopoly in the quest for efficiency does not violate the law. ${ }^{74}$ But for a firm to main-

69. United States v. Aluminum Co. of America, 148 F.2d 416, 423-24 (2d Cir. 1945).

70. Economists have criticized Judge Hand's exclusion of secondary aluminum as a component of the market Alcoa faced in selling ingots, contending that it is doubtful that Alcoa's production policies actually took account of the fact that eventually, five to twentyfive years later, some ingot aluminum came on the market again as secondary aluminum and competed for certain uses.

71. United States v. Aluminum Co. of America, 148 F.2d 416, 424 (2d Cir. 1945).

72. See Rostow, The New Sherman Act: A Positive Instrument of Progress, 14 U. Chr. L. Rev. 567, 579-80 (1947).

73. Specific intent--an intent which goes beyond the mere intent to do the act"-the court explained, is an essential element in establishing the crime of attempting to monopolize; but where, as in Alcoa's case, the possession of monopoly power has been established, it is enough that Alcoa "meant to keep, and did keep, that complete and exclusive hold upon the ingot market with which it started. That was to 'monopolize' that market, however innocently it otherwise proceeded." United States v. Aluminum Co. of America, 148 F.2d 416, 432 (2d Cir. 1945).

74. Judge Wyzanski illuminated this principle in deciding the Shoe NIachinery casc, saying:

"[T] he defendant may escape statutory liability if it bears the burden of proving that it owes its monopoly solely to superior skill, superior products, natural advan- 
tain a monopoly deliberately, seizing every opportunity for growth by forecasting demand and expanding to provide for it and in this way precluding the entry of rivals, is to monopolize in violation of the law. The court found that Alcoa had so monopolized. In reaching this conclusion the court rejected the distinction made by earlier courts between possessing power and using or abusing it. The court reasoned that every transaction by a monopolist involves the exercise of power. As the court put it, "The power and its exercise must needs coalesce." 75 It is against power over the market that the statute is directed, the power to exclude rivals and the power to control prices.

Businessmen and some students of antitrust see in these doctrines a threat to bigness. Certain pronouncements in the 1950 decision of the district court in the same case have added to their anxiety. Although the district court tempered somewhat the appellate court's condemnation of monopoly maintained through foresight, ${ }^{76}$ it retained jurisdiction over the case for five years and warned Alcoa that "if, for any reason, it should appear that [the competition of Reynolds Metals Company and Kaiser Aluminum and Chemical Corporation] ... is feeble, uncertain and ineffective," the court would take additional appropriate action. ${ }^{77}$ Whether this was an invitation to Alcoa to hold an umbrella over its weaker rivals or merely an admonition to check its own growth deliberately by refusing to utilize such competitive advantages as it might have, business leaders have interpreted the court's warning as a threat to bigness as such.

They see in the minority opinion of Justice Douglas in the Colmmbia Siecl case $^{78}$ an even more certain manifestation of hostility. United States Steel Corporation's acquisition of Consolidated Steel Corporation, said the minority,

"gives it unquestioned domination [of the Pacific Coast steel industry] ... and protects it against growth of the independents in that developing region. That alone is sufficient to condemn the purchase. Its serious impact on competition and the economy is emphasized when it is recalled that United States Steel has one-third of the rolled steel production of the entire country. The least I can say is that a company that has that tremendous leverage on our economy is big enough."

tages (including accessibility to raw materials or markets), cconomic or technological efficiency (including scientific research), low margins of profit maintained permanently and without discrimination, or licenses conferred by, and used within, the limits of law (including patents on one's own inventions, or franchises granted directly to the enterprise by a public authority)."

United States v. United Shoe Mlachinery Corp., 110 F. Supp. 295, 342 (D. AIass. 1953).

75. United States v. Aluminum Co. of America, 148 F.2d 416, 428 (2d Cir. 1945).

76. The district court took as a guide the Supreme Court's pronouncement in United States v. Columbia Steel Co., 334 U.S. 495, 526 (1948), that "no direction has appeared of a public policy that forbids, per se, an expansion of facilities of an existing company to meet the needs of new markets of a community, whether that community is nation-wide or county-wide." United States v. Aluminum Co. of America, 91 F. Supp. 333, 346 (S.D. N.Y. 1950).

77. Id. at 418.

78. United States v. Columbia Steel Co., 334 U.S. 495, 534 (1948).

79. Id. at 540 . 
Such decisions represent to business leaders and their spokesmen a drift towards a condemnation of size per se. ${ }^{80}$

From such hostility big business understandably seeks security in a return to the old rule of reason. But some advocates of change have expounded the rule quite differently from the exposition hereinbefore given, and they have coupled with it the principle of workable competition. What they seem to want is a rule of reason that will place an obligation on the courts to consider all relevant economic facts and in the light of them to reach a judgment on the question, is the arrangement complained of consistent with the principle of workable or effective competition ? ? $^{\mathbf{1}}$ That, as I understand it, is pretty close to what the Sherman Act, unamended and uncorrupted by doubtful and confusing judicial interpretations, aimed at. Unfamiliar with a professional jargon not yet created, and undisciplined in the intricacies of economic theory, Congress apparently sought to outlaw those arrangements that hindered competition-the unimpeded operation of market forces-and to encourage those that promoted it.

Such an interpretation of the rule of reason would purge it of the element of value judgment on the overall reasonableness of a restriction on competition, and would simply condemn all market arrangements that tend to make competition less effective or workable. This standard has not yet been applied; if it had been, the results in some major cases might have been different. This study will examine three industries in which the Department of Justice has at one time or another charged a dominant firm with having violated the Sherman Act-steel, cellophane and tin cans-and will try to answer the

80. Thomas E. Sunderland, general counsel, Standard Oil Co. of Indiana, voiced a typical reaction in a speech at the University of Chicago, Feb. 7, 1951:

"Underlying these trends in the law seems to be a deep-seated suspicion of big business, a suspicion which has been taken advantage of by those who want to redesign the business and industrial setup in this country. For them, and the politician as well, the attack on big business is as safe politically as a crusade against sin. As a consequence, it has not always been necessary to be entirely objective."

Sunderland, Changing Legal Concepts in the Antitrust Ficld, 3 Srracuse L. Rev. 60, 76 (1951).

81. In its 1952 report on Effective Competition, the Secretary of Commerce's Business Advisory Council declared that "to install a modernized Rule of Reason it is also neccssary to find an acceptable standard for judging competition." It offered as such a standard "effective competition," under which "there should be unhampered business incentives and freedom of choice, with reasonable alternatives for buyers and sellers." U.S. DEI'T of Conimerce, Effective Competition, Report to the Secretary of Commerce uy His Business Advisory Councit 8 (1952) (italics omitted). Oppenheim, Federal Autilrust Legislation: Guideposts to a Revised National Antitnst Policy, 50 Micu. L. REv. 1139, 1143 (1952), ties the concept of workable competition to the rule of reason morc tightly: "[T] he Rule of Reason would provide the central artery of a procedural device for considering all relevant legal and economic factors in any given factual situation. Thereby the concept of Workable Competition can be given ... substance. . .." And he recommends a "congressional declaration of national antitrust policy" which will "expressly state that the competition which the antitrust laws seek to foster and maintain is Workable Competition." Id. at 1144. 
question how each industry would have fared if tested in terms of a rule of reason embodying the standard of workable competition.

\section{Structure}

\section{The Steel Combinatiox}

The merger movement in the steel industry, which culminated in the organization of the United States Steel Corporation, transformed a market of many sellers into a market of a few sellers. As previously indicated, the Steel Corporation controlled about two-thirds of the country's production of crude steel and from one-half to four-fifths of the principal rolled steel products. In the intervening years, although it has increased its assets enormously, it has grown less rapidly than its major rivals. Yet today it accounts for approximately one-third of the country's steel ingot capacity. It is more than twice as large as its nearest rival, together with which it accounts for almost halt the country's ingot output. With eight rivals it accounts for about four-fifths. ${ }^{8:}$

The steel industry's structure is oligopolistic, and it is likely to remain that way. Entrance is so difficult that no fully integrated steel company has developed to challenge the position of the leading producers except by merger. ${ }^{83}$ Two obstacles block entry. First, steel production is a large-scale enterprise. ${ }^{84}$ Benjamin Fairless while chairman of United States Steel Corporation's board testified before the Senate Committee on Currency and Banking on March 21,1955 , that to build a steel plant from the ground up would cost $\$ 300$ per ton of crude steel capacity. ${ }^{85}$ Thus a medium-sized plant of 1,000,000-ton capacity would cost $\$ 300,000,000$. Second, new ventures with the attendant risks offer little inducement to top managerial talent. Why should well-paid steel executives managing but not owning successful corporations surrender reasonable security in a going concern to accept managerial responsibility without ownership in new enterprises whose future is uncertain?

The large optimum size of a steel company influences its costs. Fixed costs

82. Calculated from reported capacities of United States Steel Corp. and of Bethlehem, Republic, Jones \& Laughlin, National, Youngstown, Armco, Inland, and Wheeling Steel Cos., Moody's Industrials passim (1954), and from total United States capacity as reported by the American Iron and Steel Institute, 127 Steel Facts, Aug. 1954 Supp., p. 4.

83. National Steel Corporation is the most recent challenger of the majors. It was created in 1929 by merging three independent firms, including an iron ore producer. MOODY's Indostrials 3091-92 (1930). At the outset it ranked eighth among the largest steel companies; by 1935 it ranked fifth.

84. Charles F. Ramseyer, consulting engineer to the steel industry, testified before the Celler Committee that to provide the necessary facilities to convert iron ore into finished steel on an economical scale required an investment at $194 \mathrm{~S}$ prices of about $\$ 250,000,000$. Hearings Before Stbcommittee on Study of Monopoly Pouter of the House Committee on the Judiciary, 81st Cong., 2d Sess., ser. 14, pt. 4A, at 417 (1950). Ernest T. Weir, chairman of the National Steel Corporation's board of directors, testified that to duplicate the facilities of National-the nation's fifth largest producer but also the fifth smallest of the big nine-would cost $\$ 1,100,000,000$. Id. at 817 .

85. Wall Street Journa1, March 22, 1955, p. 2, col. 3. 
- that is, costs the aggregate of which do not change with changes in outputconstitute a large part of total costs. Average variable costs, the aggregate of which changes with changes in output, tend to remain constant over a wide range of output. Many of the costs encountered in making finished steel products are joint. It is difficult to allocate accurately a proper proportion of total cost to any specific product. And finally, continuous operation of a steel plant is necessary to keep average costs down. It is expensive to stop and start blast furnaces, coke ovens, and steel furnaces. ${ }^{80}$

Steelmakers believe that the demand for steel is price-inelastic; at any particular time a change in price of any given percentage will bring a smaller change in purchases. Moreover, demand is cyclical. The demand for steel is a derived demand, stemming from the demand for things made wholly or in part from steel-buildings, roads, bridges, automobiles, refrigerators, stoves and the like. Steel products are durable, and in a business recession demand for them falls off sharply. Much unused steel capacity results. In the forty years before World War II the production of steel ingots declined in periods of business recession by more than twenty per cent six times, by more than thirty per cent four times, and by more than fifty per cent twice. At the depth of the 1929-1933 depression steel companies produced less than onefourth the tonnage of steel ingots they had produced in 1929.87

Finally, steel is a homogeneous product. Steel bought from stock is standardized. Special steels are bought on specifications with which any producer can comply. One man's steel is as good as another's.

\section{Conduct}

The conduct of the industry stems from and reflects its structure. The nature of cost and the nature of demand paradoxically both stimulate and inhibit competition. Because a large part of his aggregate costs are fixed, a producer's temptation to cut prices with a decline in aggregate demand is great, and the difficulty of allocating costs precisely aggravates the temptation. With demand inelastic, price cuts may increase total industry sales but little. They will, however, shift business from one supplier to another. If one producer cuts, all must sooner or later meet the lower price or lose business. Believing that a price cut may result in approximately the same volume and distribution of business, producers are reluctant to cut. Self-restraint tends to prevent price cutting. But it is generally not enough. To avoid it, steel producers have resorted to three practices: they have followed the price leadership of the Steel Corporation $;^{88}$ they have sold steel under a basing point

86. For a more complete discussion of the economic characteristics of the iron and steel industry see Stocking, Basing Point Prictng and Regionat. Develonment c. 2 (1954).

87. Id. at 27 .

88. In 1936 the president of United States Steel testified, "I would say we generally make the prices." Hearings before the Senate Committee on Interstate Commercc on S. 4055, 74th Cong., 2d Sess. 595 (1936). Eugene Grace when president of Bethlehem Steel 
pricing system; ${ }^{89}$ and they have collectively determined the average cost of producing extras and used this as a basis in pricing them. ${ }^{00}$

The combination that in 1901 reduced the number of steel sellers and made the Steel Corporation the dominant producer facilitated these practices. The Steel Corporation from the outset busied itself with the problem of stabilizing prices. This was both Judge Elbert H. Gary's policy and his practice. As chairman of the board of the Steel Corporation he testified at a congressional hearing in 1911 that he believed competition in the steel industry inevitably tended to be ruinous and that cooperation-under government supervision if necessary-should replace competition. ${ }^{31}$ Participation by the corporation's subsidiaries in various pooling arrangements during its early history, the Gary dinners, and "Pittsburgh Plus" implemented the corporation's stabilization policy. Despite Clark's contention that in an industry with the characteristics of steel, basing point pricing tends to develop spontaneously, ${ }^{92}$ the record indicates that the industry deliberately adopted it as a device to insure identical delivered prices by rival sellers. ${ }^{93}$ Coupled with the industry's acceptance of the Steel Corporation's price leadership and its use of common freight rate

testified before the Temporary National Economic Committee in 1939 that he could not recall Bethlehem's ever having initiated a price decrease and that his company "would normally await the schedules as published by the Steel Corporation." "As a general practice," he said, the "pace is set . . . by the Steel Corporation." TNEC, Investigntio: of Concentratiox of Econonic Power, Hcarings, pt. 19, at 10601-02 (1939).

89. On July 21, 1924, the Federal Trade Commission ordered the United States Steel Corp. to cease selling steel under the "Pittsburgh Plus" system of pricing. United States Steel Corp., 8 F.T.C. 1 (1924). On October 5, 1948, the Third Circuit entered a consent decree affirming the Commission's 1924 order. United States Steel Corp. v. Federal Trade Commission, 4 Statutes and Decisions, F.T.C. 789 (1948). On August 10, 1951, the Federal Trade Commission again ordered respondents representing over \$5\% of total domestic steel production to cease quoting prices calculated according to any system or formula which produces identical price quotations. American Iron and Steel Institute, 48 F.T.C. 123 (1951).

90. The Federal Trade Commission persistently forbade the uniform pricing of extras in each of the proceedings described in note $\$ 9$ supra.

91. Hearings Before the House Connittec on Inzestigation of the United States Sted Corporation, 62nd Cong., 2d Sess. 61-297 (1911).

92. Clark, Basing Point Methods of Price Quoting, 4 Caxndinn J. Ecox. Pol. Sc. 477 (1938).

93. As usual, Judge Gary, the Steel Corporation's first president and later chairman of its board, was quite candid in describing the purpose of basing point pricing: "It was deemed necessary for the orderly conduct of the business to have one basing price, and that was not alone for the benefit of the producer, but for the benefit of the purchaser, ... so that every user of steel all over the country bought and used his steel on a certain basis, knowing in advance that everyone else who bought steel had to pay exactly as he did, with the addition of the increased freight depending upon where he wanted to use the steel." Brief for states of Illinois, Iowa, Minnesota and Wisconsin as Amici Curiac, p. S\&4, United States Steel Corp., 8 F.T.C. 1 (1924). H. P. Bope, who was with Carnegie Steel Company from 1879 to 1918, testified: "I should say that the Pittsburgh Plus system was a man-made proposition necessitated by chaotic conditions in the steel market, which seemed to render it the only available means of stabilizing the industry." Id. at $\mathbf{S 7 6}$. 
books, basing point pricing provided a means of fortifying the natural reluctance of oligopolists to engage in competitive pricing.

The industry's practice in pricing extras contributed to the same end. Under the basing point system of pricing, the published base prices covered products of specified standards. Buyers frequently wanted steel of different specifications. Differences in quality, dimensions, weight, finish, chemical content, known to the trade as "extras," all called for different prices. The possible combinations of extras varied, and costs were myriad. Without some common guide for determining their price, competitive pricing was inevitable. The industry's method of solving this problem changed from time to time. For a decade after the Steel Corporation's organization, steel companies apparently collaborated in making and distributing price lists. ${ }^{04}$ More recently technical committees of the American Iron and Steel Institute made cost studies for determining the average cost of making extras. ${ }^{05}$ The Steel Corporation used these as a basis for pricing extras, and ather companies followed suit.

These practices-uniform pricing of extras and basing point pricing-reflect the Steel Corporation's continuing live-and-let-live policy which in 1920 apparently won Supreme Court approval. ${ }^{08}$

\section{Performance}

Have the Steel Corporation's and the industry's performances been compatible with the principle of workable competition? What has been the course of steel prices? Has the Steel Corporation been an efficient producer of steel? Has it contributed to technical and industrial progress? Has it discovered new and better ways of producing steel and put them into use? Has it discovered

94. United States v. United States Steel Corp., 251 U.S. 417, 440 (1920).

95. Benjamin Fairless when president of the Steel Corporation testified: "[S] ince our motive is only to charge cost for services rendered, then obviously it is our duty to develon the best cost that exists, not only within our own company but within this industry." TNEC, Investigation of Concentration of Econonic Power, Hearings, pt. 19, at 10560 (1939). The Department of Justice after examining the extras books of twenty-five stecl companies found that each quoted identical prices for all extras covering sixteen major steel products. Id. at 10724-25. In its 1951 cease and desist order against the American Iron and Steel Institute and ninety steel companies the Federal Trade Commission forbade "any planned common course of action" to fix prices or any element thereof or to collect, compile, or exchange price lists or extra charges or deductions, or to use such lists as a factor in conputing price quotations. American Iron and Steel Institute, 48 F.T.C. 123, 152 (1951).

96. The policy, not the practices, was approved. Said the Court, "The Corporation was formed in 1901, no act of aggression upon its competitors is charged against it. . .." United States v. United States Steel Corp., 251 U.S. 417, 451 (1920). Again, "[C]ompetitors, dealers and customers of the Corporation testify in multitude that no adventitious interference was employed to either fix or maintain prices and that they were constant or varied according to natural conditions. ... [W]e may ... wonder that the despotism of the Corporation, so baneful to the world in the representation of the Government, did not produce protesting victims." $I d$. at 449 . Inasmuch as business rivals profited from these practices mutually indulged in, the wonder is after all not so great. 
new and better steel products and offered them to the public on increasingly attractive terms?

The corporation's efforts to stabilize prices did not always succeed. At times when demand was slack, basing point pricing weakened. At other times steelmakers sold below their quoted prices and discriminated among buyers. The Great Depression weakened steel prices as it did other prices. But the movement of steel prices brings into clear focus the influence of structure on price behavior. Between 1926 and their depression low points (1931-1934) the price indexes of steel products whose production was least concentrated showed the largest decline. Concentration was greatest in the production of steel rails, shapes, plates, bars and tin plate; it was least in the production of wire nails, hot and cold rolled strip, and hot and cold rolled sheets. WVith the Steel Corporation and three other companies accounting for 100 per cent of the domestic production of steel rails, their average annual base price declined only 15.4 per cent from 1926 to their depression low. With the corporation and four other companies accounting for 90.5 per cent of total capacity for making steel shapes, their average annual price declined 19.4 per cent. With the corporation and four other companies accounting for 73.3 per cent of domestic capacity for making steel plates (and ten companies accounting for 91 per cent), the average annual price declined 16.5 per cent. With the corporation and four other companies accounting for about 80 per cent of tin plate capacity, tin plate prices declined only 19.5 per cent. With the corporation and four other companies accounting for 73 per cent of domestic capacity for making steel bars, their price declined only 21.5 per cent. ${ }^{97}$ During approximately the same period wholesale prices of all manufactured commodities declined by almost 30 per cent. ${ }^{08}$

In contrast to the relatively stable prices of steel rails, plates, shapes, bars, and tin plate, the prices of wire nails, hot and cold rolled strip, and hot and cold rolled sheets were very flexible indeed. With five leading companies accounting for only 68.2 per cent of nailmaking capacity, prices declined by 29 per cent; with five leading producers accounting for 65.7 per cent of hot rolled strip capacity, prices declined 37.9 per cent. With five leading companies accounting for only 64.6 per cent of the hot rolled sheet capacity, prices declined 31.6 per cent; with the five leading companies accounting for only 43 per cent of the cold rolled strip capacity, prices declined 45.2 per cent; and with the five leading companies accounting for 61.1 per cent of the cold rolled sheet capacity, prices declined 42.3 per cent. ${ }^{00}$

97. For data on concentration of production see A3IERICAN IsoN AND STREL IrstITUTE, Directory of Iron and Steel Works of the United States and Canada (23d cd. 1938); TNEC, Investigation of the Concentration of Econonric Power, Hearings, pt. 18, Appendix, Exhibit No. 1349, Table XVII, at 10409. For data on price movements, see United States Stefl Corp., TNEC Papers, vol. II, at 76 (1940); Iron Age, Jan. 4, 1940 , p. 172.

98. Index of Manufactured Products (U.S. Bureau of Labor Statistics datz), reproduced in Report of the Jornt Consaittee on the Econoanc Report, Decenderp 1949 Steer Price INCReases, Rep. No. 1373, S1st Cong., 2d Sess. 22 (1950).

99. See note 97 supra. 
While quoted prices do not always reflect realized prices, a more recent study by the United States Burean of Labor Statistics ${ }^{100}$ reveals both the relative stability of quoted prices of eight major steel products (despite major fluctuations in output) and only minor departures of actual delivered prices from quoted prices. For example, with steel ingot production only 51 per cent of capacity in the second quarter of 1939, realized prices for steel plates were 97 per cent of quoted prices. With steel ingot production at 98 per cent of capacity in the second quarter of 1941, actual prices for steel plates were 100 per cent of quoted prices. Quoted prices for steel plates remained unchanged despite an almost 100 per cent increase in steel ingot output. The variations in quoted prices between these two periods and the departures from quoted prices were somewhat greater for hot and cold rolled sheets and hot and cold rolled strip, but about the same for merchant bars and structural shapes. ${ }^{101}$ In all instances the course of prices was impressive evidence of the effectiveness of the industry's price stabilization policy.

Apparently the corporation's preoccupation with stabilizing prices was bought at a high cost, both to consumers and to the corporation itself. In the period for which data are available, steel prices were not only relatively stable, they were relatively high. High costs made them high. The steel industry's practices described under Conduct, above, increased the average cost of shipping steel by increasing the average distance shipped and by discouraging the use of low-cost production and transportation facilities; they increased the cost of selling steel by substituting sales effort for price competition; and they increased the average cost of producing steel by encouraging inefficiency and protecting high-cost producers. The first two points should be fairly obvious. ${ }^{104}$ The third requires brief comment.

The Steel Corporation while concerning itself with stabilizing prices neglected the problem of efficiency. Apparently it was more concerned with selling steel at high prices than with making it at low cost. In its effort to

100. The Bureau's study, made in 1943, is not available in published form, but its findings were reproduced in a trade journal article, "Labor Department Examines Consumers' Prices of Steel Products," Iron Age, April 25, 1946, pp. 118-145H. Data on production in percentages of capacity for certain quarters of the years 1939 and 1941 appear in Iron Age, Jan. 7, 1943, p. 204.

101. These findings are based on data compiled by the U.S. Department of Labor, Bureau of Labor Statistics, reproduced in Iron Age, April 25, 1946, p. 118.

102. Basing point pricing results in persistent crosshauling and encourages the use of rail transportation even when cheaper water or truck transportation is available. The Ford, Bacon \& Davis 1935-1.938 survey of the Steel Corporation's operations, described in the next paragraph of the text, reportedly found that the corporation's practice of supplying Texas and its southwestern and even its Pacific Coast markets from its northern and eastern plants, instead of from its low-cost Birmingham facilities, was costing the corporation $\$ 1,000,000$ annually. The literature on the economics of basing point pricing is voluminous, including Machlup, The Basing-Point Systens (1949); Clark, stipra note 92; Kaysen, Basing Point Pricing and Public Policy, 63 Q.J. Econ. 289 (1949); Mund, The "Freight Allowed" Method of Price Quotation, 54 Q.J. Econ. 232 (1940); Stigler, A Thicory of Delivered Price Systems, 39 AMr. Econ. Rev. 1143 (1949). 
keep the whole industry orderly it failed to keep its own house in order. The corporation has itself presented the supporting evidence for these generalizations. After Judge Gary's death in the late 1920's a new management, troubled by the corporation's loss of relative position in the industry, subjected it to a severe and penetrating self-analysis. When its own engineers concluded that its operation was shot through with waste and inefficiency and proposed radical measures to overcome these deficiencies, the corporation employed a firm of industrial engineers to investigate its organization and operations in order to disprove or corroborate its own engineer's findings. In a 240volume report the outsiders confirmed the findings of the insiders. Myron Taylor, retiring chairman of the corporation's board of directors, on his own initiative told the story in a series of articles in Iron $\mathrm{Agc}$ in $1938 ; 103$ and in 1950 Benjamin Fairless while president of the corporation somewhat reluctantly brought out the details under a relentless examination by the chief counsel of the Celler Committee. ${ }^{104}$ The report as revealed by Fairless indicated that the Steel Corporation was a big, sprawling, inert giant, whose production operations were improperly coordinated; suffering from the lack of a long-run planning agency; relying on an antiquated system of cost accounting; with an inadequate knowledge of the cost or the relative profitability of the many thousands of items it sold; with production and cost standards generally below those considered everyday practice in other industries; with inadequate knowledge of its domestic markets and no clear appreciation of its opportunities in foreign markets; with less efficient production facilities than those of its rivals; and slow in introducing new processes and new products. Specifically, the report revealed that the corporation was slow in introducing the continuous rolling mill; slow in getting into the production of cold rolled steel products; slow in recognizing the potentialities of the wire business; slow to adopt the heat-treating process for the production of steel sheets; slow in getting into stainless steel products; slow in producing cold rolled sheets; slow in tin plate development; slow in utilizing waste gases; slow in utilizing low-cost water transportation because of its consideration for the railroads; in short, slow to grasp the remarkable business opportunities that a dynamic America offered it. The corporation was pictured as a follower, not a leader, in industrial efficiency.

\section{Conclusions}

This brief analysis of the steel industry's structure and conduct and of the Steel Corporation's performance warrants the conclusion that under the corporation's lead the industry did not conform to the standard of workable

103. Taylor, Tenz Years of Steel, Iron Age, April 7, 1938, pp. 70-A-71; April 14, 1938, pp. 50-53, 92-94; April 28, 1938, pp. 36-38; May 5, 1938, pp. 47, 73-75. The "outsiders" " report is the Ford, Bacon \& Davis report referred to in note 102 supro.

104. Hearings Before the Subcommittee on Study of Monopoly Pou'er of the House Committee on the Judiciary, 81st Cong., 2d Sess., ser. 14, pt. +A, at $465-673$ passim, especially $627(1950)$. 
competition. Its structure contributed to conduct incompatible with an effecm tive interplay of market forces, and its structure and conduct resulted in unacceptable performance. ${ }^{105}$ It seems not unlikely that in an antitrust proceeding based on the rule of reason and the principle of workable competition as herein expounded, the corporation would have fared badly. ${ }^{100}$

\section{The Cellophane Industry}

An analysis of the district court's opinion in the Cellophane case ${ }^{107}$ suggests that those who agitate to incorporate the principle of workable competition into the antitrust laws so that existing oligopolistic structures may be preserved have won their campaign without a battle. It also suggests that the principle may be a treacherous guide to courts not schooled in the intricacies of economic analysis. In formulating his opinion Judge Leahy stated that the case raised two questions: "(1) Does du Pont possess monopoly power in making and selling cellophane? (2) If so, has it been guilty of monopolizing within the meaning of the Sherman Act as interpreted in the Aluminum case?"108 The court reasoned that if it answered "no" to the first question, it need not consider the second. It was quite positive in its conclusion, for it stated: "Facts, in large part uncontested, demonstrate duPont cellophane is sold under such intense competitive conditions acquisition of market control

105. More detailed studies have led to similar conclusions. See Marengo, Basing Point Pricing in the Steel Industry (unpublished doctoral dissertation, Harvard University, June 1950) ; Stocking, Basing Point Pricing and Regional Development c. 6 (1954).

106. It should be noted that the Steel Corporation of the 1930's is not the Stecl Corporation of today. According to Fairless' testimony before the Celler Committce, Hcarings Before the Subcommittee on Study of Monopoly Power of the House Commiltec on the Judiciary, supra note 104, the corporation adopted such of the engineers' suggestions as it felt warranted. The corporation has reorganized, modernized, and expanded its facilitics and operations at a cost of hundreds of millions of dollars, and Fairless' modest contention that the corporation is today as efficient as any of its rivals, $i d$. at 631 , seems reasonable. But that the industry's structure still impedes competitive price adjustments with changes in demand is indicated by recent price movements. Between July 1953 and July 1954, whon production of ingots and steel for castings declined from $93.1 \%$ of capacity to $68.1 \%$, the price of cold rolled and hot rolled strip, cold rolled and hot rolled sheets, and stcel plates remained unchanged. Iron Age, Jan. 6, 1955, p. 340. In July 1954, when production dropped to $62.9 \%$ of capacity, United States Steel raised steel prices. The Steel Corporation's explanation of this anomaly was an increase in labor costs. Wall Street Journal, July 2, 1954, p. 1, col. 2. Other companies followed the lead. Iron Age, July 8, 1954, pp. 146-48; July 15,1954 , pp. 106-68.

107. United States v. E.I. du Pont de Nemours \& Co., 118 F. Supp. 41 (D. Del. 1953). The discussion that follows in the text is based on the record in this case. Government exhibits contained in the record will be designated GX and defendant's exhibits DX. The title of the case will be repeated only for references to the opinion. For a more comprchensive analysis of the economic isstues involved in the case, see Stocking \& Mueller, Thic Cellophane Case and the New Competition, 45 AMr. ECoN. Rev. 29 (1955).

108. United States v. E.I. du Pont de Nemours \& Co., 118 F. Supp. 41, 54 (D. Del. 1953). 
or monopoly power is a practical impossibility."109 This study challenges the validity of the court's conclusion that du Pont had no monopoly in selling cellophane, though it leaves to the Supreme Court the question whether such monopoly power as du Pont may have had violates the statute. ${ }^{110}$ In challenging the district court's conclusions the analysis will consider du Pont's strategy (conduct) in protecting cellophane from the competition of rival products; analyze the structure of the cellophane industry and its market; and evaluate du Pont's performance in making and selling cellophane.

\section{Conduct}

In 1923 du Pont entered into contracts with the world's sole producer of cellophane, Comptoir des Textiles Artificiels, a French corporation, which granted to a jointly owned company, Du Pont Cellophane Company, Inc., the exclusive right to the Comptoir's patents and know-how in making and selling cellophane in the North and Central American market.11 Du Pont at this time recognized that the patents might not guarantee it complete protection from rival producers but considered that the patents together with the trade skills and technical knowledge accompanying them justified an investment of some $\$ 2,000,000$, on which it anticipated annual earnings of over $\$ 600,000$, or earnings at an annual rate on investment of over thirty-one per cent.112 Believing that it had a highly differentiated if not a unique flexible wrapping material for which a large and expanding market could be readily developed, it sought to protect itself from the competition of other producers of cellophane. To do this it proceeded on both domestic and foreign fronts. To curb imports of cellophane it both sought a tariff increase ${ }^{113}$ and made agreements with foreign producers providing for a division of markets. While it did not succeed immediately in getting a direct tariff increase, it obtained a reclassification of cellophane which on February 24, 1929, raised the duty from twenty-five to sixty per cent ad valorem. The higher duty soon reduced annual foreign sales in the American market from more than twenty per cent of the total domestic business to less than nine per cent. ${ }^{114}$ The Tariff Act of

109. Id. at 197-98.

110. On October 14, 1954, the Supreme Court noted probable jurisdiction. United States v. E.I. du Pont de Nemours \& Co., 348 U.S. 806 (1954).

111. Option contract of Jan. 6, 1923, GX 1458, pp. 5999-6008; organizational agrecment of June 9, 1923, GX 1001, pp. 989-997; license agreement of Dec. 26, 1923, GX 1002, pp. 998-1001.

112. Report of Dr. Fin Sparre, head of du Punt's development department, April 14, 1923, GX 392, p. 5451.

113. About du Pont's effort to get higher duties on cellophane L. A. Yerkes, president of Du Pont Cellophane Co., Inc, wrote W. C. Spruance, du Punt vice president, on July 25, 1925: "In order that you shall be entirely familiar with the Cellophane status, I want to let you know that we are endeavoring to have the duty on Cellophane raised from $25 \%$ to $45 \%$, and Curie, Lane and Wallace are of the opinion that we have a fair chance of getting this through." GX 1068, p. 1142.

114. Du Pont Cellophane's quarterly competitive report, first quarter 1929, reported that importers had had $21 \%$ of domestic business in 1927 and $24 \%$ in 1928. GX 431, p. 5677. 
1930 fixed the duty on imported cellophane at forty-five per cent ad valorem -a smaller duty than the reclassification had brought but still enough to keep foreign cellophane out of the United States market. From 1930 to 1947 annual cellophane imports accounted for less than one per cent of domestic consumption. 115

On May 7, 1929, du Pont entered a patent exchange agreement with Kalle \& Company, Germany's exclusive cellophane producer under the Comptoir patents, by which the parties agreed to exchange without charge except for patent fees all patent rights and technological data covering cellophane, that they then had or might later get.116 The agreement, according to C. M. $\Lambda 1$ bright, Du Pont Cellophane's vice president, did not "for obvious reasons" designate the countries within which Kalle got exclusive rights, but Albright listed them in a letter for the benefit of du Pont's Buffalo office. ${ }^{117}$ Later du Pont assigned Kalle exclusive patent rights on moistureproof cellophane in the countries of Kalle's territory. ${ }^{118}$ In $1935 \mathrm{du}$ Pont and British Cellophane Limited entered into a similar patent exchange agreement which specifically designated the areas within which each party would confine its operations. ${ }^{110}$ Meanwhile on February 12,1930, all the world's leading cellophane producers except du Pont had entered into a cartel agreement assigning markets and fixing quotas. ${ }^{120} \mathrm{Du}$ Pont representatives attended the first day of the conference as guests but did not sign the agreement. The trial court found that they were not authorized to make any commitment and did not. ${ }^{121}$ Nevertheless, the agreement, which did not cover moistureproof or photographic cellophane, recognized the North American market as belonging to du Pont and Sylvania Industrial Corporation of America. ${ }^{122}$ The subsequent course of the

Its report for the fourth quarter 1.929 showed that du Pont had $91.6 \%$ of domestic business. GX 434, p. 5714. The increased tariff and decreased imports apparently contributed to the stability of cellophane prices. Du Pont Cellophane's competitive report, second quarter 1929, said:

"The present tariff rate (.40 per pound) as fixed by the United States Customs Court, has increased the cost of importing Transparent Cellulose Sheeting to stich an extent that the competitors are adhering more rigidly to their published price list. Their selling policy in the past has been to obtain preference with the manufacturer by offering special price concessions."

GX 432, p. 5690 .

115. GX 182A, p. 515A; GX 182, p. 515.

116. GX 1087, pp. 1183-86.

117. Letter of Oct. 30, 1929, GX 1091, p. 1195.

118. Du Pont Cellophane memorandum dated March 17, 1933, GX 1098, p. 1205 ; Letter to Kalle dated March 20, 1933, GX 1099, p. 1206; memorandum dated April 27, 1934, review of the du Pont-Kalle relations, prepared by du Pont's patent service, GX 1102, pp. 1210-12.

119. Agreement of May 3, 1935, GX 1109, pp. 1229-34.

120. "Official report," signed by producers, GX 1414, pp. 1841-44.

121. United States v. E.I. du Pont de Nemours \& Co., 118 F. Supp. 41, 221 (D. Del. 1953).

122. Sylvania had come into the American market by the back door. Sociéte Industrielle de la Cellulose (SIDAC) had built a cellophane plant in Belgium using the Comp. 
cartel is not clear, but apparently it broke down under the strain of the Great Depression and World WVar II. In 1940 du Pont disavowed all formal territorial limitations, ${ }^{123}$ although its agreements with Kalle and British Cellophane were to have run for twenty years.

On the domestic front, in 1930 du Pont found itself confronted by a rival producer, the Sylvania Industrial Corporation of America. To improve cellophane's usefulness as a wrapping material and to fortify it against domestic competition, du Pont had already developed and patented a moistureproof product. The initial moistureproof cellophane product patent, issued in 1929, was broad in scope and comprehensive in its claims. ${ }^{124}$ Having improved its patent postion, du Pont notified Sylvania, which meanwhile had developed a moistureproof cellophane of its own, that it was infringing du Pont's patents. Eventually du Pont sued Sylvania but settled the suit by a patent exchange and licensing agreement, under which Sylvania agreed to pay du Pont a two per cent royalty on its net sales of moistureproof cellophane in return for the use of du Pont's patents. For sales in excess of twenty per cent of total domestic sales, Sylvania agreed to pay a royalty of twenty cents a pound or thirty per cent of net sales, whichever was higher. Its penalty-free share of

toir's patented processes and secret know-how, which it had obtained from two former employees of the Comptoir's French affiliate, La Cellophane, Société Anonyme. Mremorandum of Feb. 17, 1944, on the history of du Pont cellophane, prepared in du Pont's cellophane division, GX 1, p. 12. SIDAC at first exported to the American market and later established Sylvania as its American subsidiary. Du Pont Cellophane Company's quarterly competitive report, third quarter 1929, GX 433, p. 5702. When La Cellophane sued SIDAC for patent infringement and in settlement took stock in SIDAC, this brought La Cellophane indirectly through Sylvania into competition with du Pont in the American market in violation of its 1923 contract. After prolonged negotiations for a settlement with La Cellophane, during which du Pont pondered how to "accept reparations and at the same time protect its future position without contravening American statutes," memorandum of a Nov. 14, 1929 discussion by du Pont officials, GX 1410, p. 1831, La Cellophane waived the 1923 restrictions confining du Pont to the North and Central American markets and granted it equal rights with itself in Japan and South America. Letter of March 6, 1930, from du Pont to La Cellophane, GX 1013, pp. 1027-29; excerpt from minutes of Miay 8, 1930, meeting of du Pont's board of directors, GX 1015, p. 1031.

123. Identical letters dated Oct. 17, 1940, to Kalle, British Cellophane, Canadian Industries Limited, and La Cellophane, GX 1273, p. 1602; GX 1274, p. 1603; GX 1275, p. $1604 ;$ GX 1276, p. 1605.

124. About its research program to improve cellophane, L. A. Yerkes, president of Du Pont Cellophane, later said:

"This work was undertaken as a defensive program in connection with protecting broadly by patents the field of moistureproofing agents other than waxes which was the only class of material disclosed in our original Cellophane moistureproofing patents. The investigations on this subject did, in fact, lead to the discovery of a number of classes of materials which could serve equally well for moistureprooting agents. ... Each of these classes has been made the subject of a patent... Altogether, 13 patent applications are being written as a result of the work done under this project, all in view of strengthening our Moistureproof Cellophane patent situation." December, 1933, report to Du Pont Cellophane's board of directors, Jan. 22, 1934, GX 488 , p. 6478. 
the market was to be graduated upward at intervals of one per cent per annum until by 1942 it was scheduled to reach twenty-nine per cent. ${ }^{125}$ For such use if any as it should make of Sylvania's patents, du Pont agreed to a similar penalty for exceeding its basic quotas, but it never used Sylvania's patents.

This settlement apparently was based on a mutual recognition that if du Pont won the suit Sylvania would be foreclosed from producing cellophane except on such terms as du Pont might impose, and if Sylvania won both parties would lose to an intensification of competition. ${ }^{126}$ Whatever the purpose of the penalty royalty, it in effect geared Sylvania's output to du Pont's and gave du Pont as the dominant firm the power to determine how much moistureproof cellophane would come on the market. ${ }^{12 \pi}$

Du Pont's efforts to protect itself from the competition of rival cellophane producers was the strategy of a monopolist. Its conduct is consistent only with the belief that in cellophane du Pont had a highly differentiated if not a unique product in exploiting which it had something to gain by being the single seller.

\section{Structure}

Any innovator has a temporary monopoly. The questions crucial to the economic significance of his monopoly-to its becoming workably competitiveare whether rival producers of the identical product appear, or whether substitute rival products with a sufficiently high cross-elasticity of demand exist or appear.

An examination of the structure of the cellophane industry and of changes in it over the years throws light on these questions. In truth, the analysis of conduct has already answered the first question. Du Pont's strategy succeeded in keeping rival cellophane producers except Sylvania out of the domestic market, and the way in which the two companies settled their patent infringement suit geared Sylvania's production of cellophane to du Pont's. No other

125. Agreement dated April 26, 1933, GX 2487, pp. 3212-33.

126. Du Pont's patent attorney, after a conference with Sylvania's general counsel, summed up the situation as follows:

"During the conference Mr. Menken stated that in his opinion the case should be settled. He said that they were very fearful of what the result would be to their company in the event they succeeded in having the claims of the patents which are involved in the litigation held invalid. He seemed to realize the old adage that the defendant can never win. ... If the Du Pont Cellophane Company surcceeds and the patents are held to be infringed, Sylvania Industrial Corporation will be under injunction and will be obliged to stop manufacturing moistureproof wrapping tissue. On the other hand, if they succeed in having the broad claims of the patents held invalid they will throw the art open, so far as the broad claims are concerned, to anyone and therefore will have additional competition."

Letter dated Aug. 4, 1932, from W. S. Pritchard to B. M. May, Du Pont Cellophane vice president, GX 2811, pp. 6073-74.

127. In 1945, as the court pointed out, the parties agreed to smaller royalties and abaudoned the penalties. United States v. E.I. du Pont de Nemours \& Co., 118 F. Supp. 41, 158 (D. Del. 1953). 
rival producer of cellophane had appeared when the Government instituted its antitrust proceedings. ${ }^{128}$

The second question-whether there was a high cross-elasticity of demand -involves an analysis of the market for flexible wrapping materials. The court concluded that no separate identifiable market for cellophane existed; the market for cellophane was identical with that for flexible wrapping materials. ${ }^{129}$ It was largely on this finding that the judge based his conclusion as to the effectiveness of the competition du Pont encountered in selling cellophane.

A characteristic of a competitive market is that the prices of identical products tend to be identical. Where the products are nonidentical, their prices will reflect the comparative evaluation that marginal buyers (those just induced to buy at the prevailing prices) make of their want-satisfying qualities. For a product that a consumer regards as better satisfying a particular requirement he will be willing to pay more. The higher price that he pays will result in higher profits to the producer of the preferred article, unless perchance it costs more to make it. If obstacles to entry do not exist, the higher profits will attract additional producers, and price must eventually decline until it equals average cost. If differentiated but competitive products are selling at competitive even though nonidentical prices, a change in the price of one will affect the amount of the other that can be sold at prevailing prices. A price decline in one will decrease the other's sales and hence tend to lower its price. If the initial price decline reflects a reduction in cost, unless the seller of the rival product can lower his cost, eventually he must go out of business. Before he does so he no doubt will lower his price. Thus a decline in the price of one differentiated product tends to bring a decline in the price of a rival product. Contrariwise an increase in the demand for products of the same general class which brings an increase in the price of one of several differentiated products will tend to raise the price of all. In short, although price differences may exist which reflect differences in cost among differentiated products and differences in the importance that consumers attach to them, the prices of the differentiated products tend to move in unison. Cost-price relationships may thus be helpful in determining whether differentiated products do in fact meet in a common market.

Does cellophane compete with all other flexible wrapping materials in a single market? Flexible wrapping materials fall into four major categories: opaque nonmoistureproof wrapping paper, moistureproof films, nonmoisture-

128. The Government filed its suit December 13,1947, but the case was not decided until December 14, 1953; and a third producer, Olin Industries, Inc, began the production of cellophane in June 1951, while the case was being tried. Testimony of Fred Olsen, Olin vice president, Transcript of Testimony, p. 6829, United States v. E.I. du Pont de Nemours \& Co., 118 F. Supp. 41 (D. Del. 1953).

129. Judge Leahy said: "The relevant market for determining the extent of du Pont's market control is the market for flexible packaging materials. ..." United States v. E.I. du Pont de Nemours \& Co., 118 F. Supp. 41, 60 (D. Del. 1953 ). 
proof films, and moistureproof materials other than films. Cellophane by reason of its qualities and its price is apparently excluded entirely from the market of the principal opaque nonmoistureproof wrapping paper-kraft. Kraft paper is used primarily for convenience and protection in handling packages. The housewife brings her groceries home in it. It sells for less than cellophane costs, and for general wrapping it meets consumers' needs better. Clearly its market is not cellophane's.

Cellophane is a film of regenerated cellulose-thin, transparent, nonfibrous. It is sold in both moistureproof and nonmoistureproof form. Its leading moistureproof film rivals include Saran, cellulose acetate, polyethylene, and pliofilm. In 1949 their prices ranged from over forty per cent to over 160 per cent higher than the price of moistureproof cellophane, ${ }^{130}$ and they were less satisfactory for most uses to which cellophane was put. Data are not available to compare the trend of the prices of these films with the prices of cellophaneexcept for cellulose acetate, which du Pont itself made-but a du Pont market analysis report for 1948 makes it clear that du Pont did not regard the rival films as competitive:

"The principal markets for non-viscose films have been competitive with Cellophane only to a very minor degree up to this time. Some are used very little or not at all in the packaging field-others are employed principally for specialty uses where Cellophane is not well adapted-none have been successfully introduced into any of Cellophane's main markets due to their inherent shortcomings."131

The combination of cellophane's qualities is such that in one important segment of the flexible packaging material market it has captured the market completely. In recent years, save during temporary periods of shortage, cigarette makers have used no other overwrap. ${ }^{132}$ But in the food packaging industry, which in 1949 accounted for eighty per cent of du Pont's cellophane sales, cellophane encounters several lusty rivals-vegetable parchment, greaseproof paper, glassine, waxed paper, and aluminum foil. In 1949 cellophane

130. This comparison, in terms of prices per thousand square inches, rests on data appearing in a price survey made for du Pont by Robert Heller \& Associates, management consultants. DX 995, reproduced in part in United States v. E.I. du Pont de Nemotrs \& Co., 118 F. Supp. 41, 83 (D. Del. 1953).

131. DX 595, p. 1147. Olin Industries, Inc., later to become the country's third producer of cellophane, concluded similarly :

"There are no films currently marketed which are potentially competitive to any" substantial degree in Cellophane's major markets. ... Other transparent films will find their place for those low volume uses which can absorb the additional cost of the film and which necessitate certain physical properties not possessed by Cellophane."

Report on "the evidence in support of entry by Olin Industries into the Cellophane business, based on the purchase of patent license and 'know-how' from du Pont," Dec. 15, 1948, GX 566, p. 7575 .

132. Judge Leahy referred to cellophane's temporary "displacement" by other cigarette overwraps in the mid-forties, when cellophane was in short supply. United States v. E.I. du Pont de Nemours \& Co., 118 F. Supp. 41, 108 (D. Del. 1953). 
accounted for 6.8 per cent of the total quantity of selected flexible wrapping materials (in millions of square inches) sold by nineteen major converters for wrapping bakery products, 24.4 per cent of that used in wrapping candy, 31.9 per cent of that used in wrapping snachs, 34.9 per cent of that used in wrapping meat and poultry, 26.6 per cent of that used in wrapping crackers and biscuits, 47.2 per cent of that used in wrapping fresh produce, and 33.6 per cent of that used in wrapping frozen foods excluding dairy products. ${ }^{133}$

Certainly on their face these figures do not indicate that cellophane monopolized the market for flexible wrapping materials. Moreover, the court found that "shifts of business between du Pont cellophane and other flexible pacliaging materials have been frequent, continuing and contested."134 In the face of these facts and this judgment, how can economists justify the conclusion that du Pont exercised monopoly power in selling cellophane? First, note that a monopolist's pricing policy does not guarantee that he will get all the business he would like to have at any particular moment. His pricing policy is designed to maximize earnings over some period of time. He may revise prices from time to time in response to changing cost and demand functions. But having determined the price at which he will sell for a period of time, he foregoes business that he might have had at a lower price. If he could isolate his markets, it would pay him to discriminate among customers and get both the low-price and the high-price business; but if he cannot, by cutting prices he will realize less on what he might have sold at the higher price. To compensate for this, after deciding on a price policy at any particular time he may rely more on sales effort than on price competition. H. O. Ladd, director of du Pont's trade analysis division, put it this way:

"The main competitive materials ... against which Cellophane competes are waxed paper, glassine, greaseproof and vegetable parchment paper, all of which are lower in price than Cellophane. Tre do not meet this price competition. Rather, we compete with these materials on the basis of establishing the value of our own as a factor in better pacliaging and cheaper distribution costs and classify as our logical markets those fields where the properties of Cellophane in relationship to its price can do a better job for the user."135

A more reliable test of monopoly power than the percentage of a broad, ill-defined market that a particular seller holds is the one set up here-the relative price movements of the single seller's product and of "competing" products. Stated in technical terms the question becomes: Is the cross-elasticity of demand so low that du Pont can price cellophane independently and still make monopoly profits in selling it ?136

133. Id. at 111-13. A detailed comparison appears in the opinion.

134. Id. at 91 .

135. GX 589, p. 7530 .

136. The Supreme Court recognized the significance of cross-elasticity of demand in Times-Picayune Publishing Co. v. United States, 345 U.S. 594, 612 n.31 (1953). It said:

"For every product, substitutes exist. But a relevant market cannot meaningfully encompass that infinite range. The circle must be drawn narrowly to exclude any 
The course of moistureproof cellophane prices shows that du Pont has followed a farsighted policy in pricing cellophane. While at any particulatr time it has apparently foregone price competition to get business, it has deliberately adopted a long-range pricing policy designed to expand sales continuously. From an average price of $\$ 2.508$ a pound in 1924, du Pont reduced cellophane prices every year until 1936, when its prices averaged 41.3 cents a pound. ${ }^{137}$ By 1940 further reductions had brought the annual average price down to thirty-eight cents a pound. With the war and postwar inflation du Pont reversed cellophane's price trend. By 1950 it was charging an average of fortynine cents a pound. But despite this long downward trend in prices, the principal type of moistureproof cellophane (300 MST-51) sold continuously at from two to seven times the price of $25 \#$ bleached glassine and from two to four and a half times the price of $30^{\#}$ waxed paper, its most important rivals. ${ }^{148}$

What is more important, du Pont cellophane prices moved independently of rival products' prices, which remained relatively stable or moved slightly upward ${ }^{139}$ while cellophane prices were dropping sharply. When the war and postwar inflation brought higher prices for these wrapping materials, du Pont cellophane, which had continually sold at higher prices, moved up with the rest, but less rapidly. Thus it continued its relative decline in price. Such independent price movements suggest noncompetitive pricing as between cellophane and the rival products. That the sellers of the other wrapping materials did not reduce their prices as cellophane prices were moving downward indicates a low cross-elasticity of demand between the products. It suggests, although it does not prove, that the rival products were selling too close to average cost at the time when cellophane, which was continuously higher in price despite its downtrend, was selling above its average cost. Apparently rival products were not sufficiently close substitutes to constitute effective competition with cellophane. ${ }^{140}$

other product to which, within reasonable variations in price, only a limited number of buyers will turn; in technical terms, products whose 'cross-elasticities of demand' are small."

137. United States v. E.I. du Pont de Nemours \& Co., 118 F. Supp. 41,82 (D. Del. 1953) (table of annual average prices from 1924 to 1950 ).

138. Brief for Defendant, Appendix A (graph based on prices per thousand scluare inches), United States v. E.I. du Pont de Nemours \& Co., 118 F. Supp. 41 (D. Del. 1953).

139. Bleached glassine prices were unchanged from 1924 to 1933 and again from 1934 to 1938. They rose in 1939 and again in 1940. Waxed paper prices were virtually unchanged from 1933 to 1940 , fluctuating between $.5 \mathrm{c}$. and $.52 \mathrm{c}$. per thousand square inches. They increased to $.62 \mathrm{c}$. in 1940 . Between 1924 and 1928 vegetable parchment prices declined slightly from $1.3 \mathrm{c}$. to $1.0 \mathrm{c}$ per thousand square inches and thereafter remained relatively stable, moving between $.95 \mathrm{c}$. and $1.05 \mathrm{c}$. Bleached greaseproof prices rose from $.45 \mathrm{c}$. per thousand square inches in 1933 to $.55 \mathrm{c}$. in 1940 . These price comparisons rest on data collected for du Pont by Robert Heller \& Associates, management consultants. DX 994-A. The price of one principal standard type of each material was used.

140. The judgment of a du Pont division manager supports the above conclusiom. During the war and early postwar years increased taxes brought a lower rate of net earnings on du Pont's cellophane investment, reducing it from $20.4 \%$ in 1940 to $11.2 \%$ in 


\section{Performance}

Some economists would regard the cellophane industry's record of performance as good when measured by the course of prices. Certainly du Pont's long-run pricing policy was farsighted; however, it was not inconsistent with that of a monopolist. A monopolist interested in maximizing earnings must not only take account of the short-run effect on profits of price changes but most also consider their long-run effects on costs and sales. He may find, as du Pont apparently did, that lower prices eventually increase sales and thereby lower costs and increase earnings. In determining its long-run pricing policy du Pont sought larger earnings through increased volume. ${ }^{141}$ Whether its pricing policy maximized its earnings is not clear, but that it kept them at a high level is beyond dispute. From 1924 to $1950 \mathrm{du}$ Pont's rate of operative earnings (before taxes) on investment in cellophane ranged from 62.4 per cent in 1928 to 19.1 per cent in 1947. In 1950 it reached a postwar high of 45.3 per cent. Over a twenty-six year period it averaged 34.4 per cent. The rate of net earnings (after taxes) ranged from 51.5 per cent in 1928 to 8.4 per cent in 1942. In 1950 it reached a postwar high of twenty per cent. Over the twenty-six year period it averaged 24.2 per cent. ${ }^{122}$

On their face these look like noncompetitive earning rates. But many factors besides the intensity of competition affect earnings, and a sustained high rate of earnings in a particular product does not prove that earnings are monopolistic. Cellophane has met a rapidly expanding demand, as have other wrapping materials. Unfortunately data are not available for comparing cello-

1947. 1947 profit and loss statement of du Pont's cellophane division, GX 591, p. 7539. To reverse this trend du Pont raised cellophane prices from an average of $41.9 \mathrm{c}$. a pound in 1947 to $46 \mathrm{c}$. in 1948. By May 1948, du Pont's rate of earnings on its cellophane investment had increased to $31 \%$. At this time du Pont's cellophane division manager announced that "if operative earnings [before taxes] ... of 31 per cent is [sic] considered inadequate, then an upward revision in prices will be necessary to improve the return." The manager proposed a schedule of prices to earn about $40 \%$. Du Pont put this into effect in August 1948. Operative earnings for that year averaged only 27.2\% (calculated from 1948 profit and loss statement, GX 577, p. 7323), but by 1949 they had increased to $35.2 \% \mathrm{C}$ and by 1950 to $45.3 \%$. The latter figure represented net earnings of $20 \%$ on du Pont's 1950 investment in cellophane facilities. GX $573(\mathrm{I})$, p. 8. (This exhibit was impounded by the court but was cited in the Government's Proposed Findings of Fact, p. 48, and Brief for the United States, pp. 144-45, United States v. E.I. du Pont de Nemours \& Co., 118 F. Supp. 41 (D. Del. 1953).)

141. President Yerkes of Du Pont Cellophane had concluded as carly as 1924 that the company should lower cellophane prices. "[I] think it will undoubtedly increase sales and widen distribution.... Our price I think is too high based purely on manufacturing cost and too high in comparison with other wrapping papers. ..." Memorandum of some remarks made at a meeting of the board of directors, Du Pont Cellophane Co., Inc., Dec. 11, 1924, DX 337, p. 643. Walter S. Carpenter, Jr., chairman of du Pont's board of directors, testified that "the purpose of reducing our price and also improving our quality" was to broaden our market. ..." Transcript of Testimony, p. 6278, United States v. E.I. du Pont de Nemours \& Co., 118 F. Supp. 41 (D. Del. 1953).

142. Stocking \& Mueller, The Cellophane Case and the New Competition, 45 Ass. ECON. Rev. 29, 57 n.107, 59 (1955). 
phane's earning rates with those of rival materials. However, du Pont's rate of earnings on cellophane-of which for half a clozen years du Pont was the sole domestic producer and thereafter until 1951, with Sylvania, one of two producers-can be compared with clu Pont's earnings on its rayon investment before World War II. Many similarities in the two industries justify the comparison. Du Pont produced both products. They stem from the same raw materials. They were initially both produced under noncompetitive conditions. Both enjoyed tariff protection. Both have close substitutes. Both have been characterized by rapid expansion in consumption, rapid reduction in cost, and a rapid decline in price. The single relevant difference is the structure of the two industries. Rayon production began as a monopoly, with American Viscose Corporation the sole producer until after World War I, when du Pont entered the field; by 1930 eighteen rivals confronted the two leaders. ${ }^{143}$ In 1920, when du Pont first engaged in rayon production, American Viscose made 64.2 per cent on its investment before taxes. ${ }^{144}$ Entry was relatively free, however, and the high rate of earnings attracted newcomers. By 1929 earnings for the industry averaged 18.1 per cent before taxes; du Pont made nineteen per cent. ${ }^{145}$ With six more firms entering the industry in 1930, the average return for the industry was only five per cent, and du Pont lost money, it losses equaling 0.9 per cent of its investment. During the next eight years du Pont averaged 7.5 per cent on its rayon investment. ${ }^{140}$ On cellophane it averaged over twenty-five per cent. This significant difference in earnings probably reflects the relative intensity of competition.

\section{Conclusions}

The foregoing analysis indicates that cellophane production has not conformed to the conception of workable competition developed herein. Du Pont's conduct (strategy) was that of a monopolist. The industry's structure has been oligopolistic; and the market for cellophane, while not clearly defined, is scarcely identical with that for flexible wrapping materials. If entry had been free and genuine rivals had confronted du Pont in selling cellophane, ${ }^{147}$ $\mathrm{du}$ Pont would have been forced to sell it for less and would have made a lower rate of return.

143. Markham, Competition in the Rayon Industry 46 (1952).

144. FTC, Investarents, Profits, and Rates of Return for Selected Inuustries 17985 (a special report prepared for the TNEC, 76th Cong., 3d Sess. (1941)).

145. Id. at $17899,17990,17998$.

146. Ibid.

147. Correspondence between Lammot du Pont and L. A. Yerkes, president of du Pont Cellophane, reveals the attitude of potential rivals towards competing with du Pont (and incidentally du Pont's attitude towards the competition of rivals). Written at a time when the Union Carbide \& Carbon Corp. had considered entering the field, du Pont's letter of December 2,1931, which was based on an hour's conversation with representatives of the Union Carbide \& Carbon, stated: "They assured me repeatedly they did not wish to rush into anything, most of all a competitive situation with du Pont. Their whole tone was most agreeable. ... In the course of the conversation, various efforts at co-operation betwcen 
But the fact that cellophane has not been sold under conditions of workable competition does not mean that the industry's performance has been wholly bad. Far from it. Du Pont has continuously improved the product, developed new types, found new uses for them, lowered its price, helped converters and packagers in developing new markets, and developed and improved packaging machinery. It has been a most progressive rival wherever flexible wrapping materials are sold. The district court would have been on sounder ground had it concluded that cellophane has been sold under conditions of workable monopoly, and it is this confusion between workable monopoly and workable competition that makes this decision a bad precedent. Rarely does a monopolist sell in a completely isolated market. In one sense every wantsatisfying product must compete with all others for the consumer's dollar, and the rivalry among the sellers of rival products may be intelligent and vigorous. But it is a deceptive rivalry, which if accepted by the courts as a substitute for competition will narrow greatly the applicability and probably the usefulness of the Sherman Act.

\section{The Tin Can Industry}

The district court's decision in the 1916 Amcrican Can Company case ${ }^{48}$ affords a striking illustration of the unfortunate implications of the rule of reason as laid down in Standard Oil and American Tobacco. The organizers of the American Can Company with a single exception were promoters, not canmakers. They set out to monopolize canmaking ${ }^{140}$ and to make money in the manipulation of securities. Immediately they succeeded in both endeavors. American Can acquired over a hundred canmaking plants, for most of which it paid exorbitant prices, ${ }^{150}$ and two-thirds of which it dismantled within two years. Together these plants accounted for ninety per cent or more of the cans sold in the domestic market.151 To make their monopoly enduring the

Carbide and du Pont were referred to, and in every case assurances of their desire to work together, given." GX 4381, p. 4300.

148. United States v. American Can Co., 230 Fed. 859 (D. AId. 1916), decree rendered, 234 Fed. 1019 (D. Md.), appeal dismissed, 256 U.S. 706 (1921). Statements of fact in the text about the can industry in 1916 and earlier are based on the opinion in this case unless otherwise indicated.

149. Said the court, "What has been proved is ... that the defendant was organized to monopolize interstate trade in cans. ..." United States v. American Can Co., 230 Fed. 859,861 (D. Md. 1916). "There can be no possible explanation of such transactions, except that the defendant and its promoters wanted to extinguish competition and did not stop to inquire how much it would cost to do so." Id. at 877.

150. Judge Rose found that the prices paid ranged from one and a half to twenty-five times the value of the property acquired, and he said that for half or probably a third of the $\$ 25,000,000$ given in cash or capital stock American could have "purchased land, creeted buildings, and equipped them with machinery which would have had a greater capacity, could have operated at a smaller cost, and would have been at least as well, if not better, located...." Id. at 870-71.

151. Id. at 869 . In arriving at the $90 \%$ figure the court noted that one vitness had testified that he believed that American Can had at the outset acquired from 95 to $98 \%$ of the country's total capacity for making cans for sale. 
promoters obtained agreements from most of the former plant owners not to engage in canmaking for fifteen years within three thousand miles of Chicago, and they worked out various arrangements with the manufacturers of canmaking machinery designed to prevent potential rivals from becoming can* makers. ${ }^{152}$ Exercising its monopoly power, American Can obtained secret rebates from the American Sheet and Tin Plate Company, a United States Steel subsidiary, amounting over a twelve-year period to $\$ 9,000,000$. As had the Standard Oil and American Tobacco Companies, American Can operated bogus independents.

Despite its having achieved at the outset a virtual monopoly of canmaking and despite its early "bad" conduct, the court found American's contemporary performance good. The company made good cans and sold them at prices against which customers did not complain. The company claimed (as the court put it, "with much reason") that it was the first to study can industry problems systematically and scientifically, and it spared no effort to meet its customers' needs. It had a more varied line of equipment than its rivals and "having great facilities habitually used them to give intelligent, courteous, and kindly aid [to its customers]. It is unmistakably popular in the trade."16a With its plants widely dispersed it could make prompt deliveries, which the court regarded as perhaps "its most valuable service to the trade."164

Not only did the court find its performance good, but it found that American Can had reformed its conduct: "[T] he testimony has disclosed nothing in the recent conduct of defendant, other than that which the government particularizes, to which any serious exception, or indeed any exception at all, can be taken." 155

And finally the industry's structure had changed somewhat. The court found that American Can by 1913 was selling only about half the cans sold in the United States. Continental Can Company sold approximately one-fourth of the cans not sold by American, and numerous smaller concerns accounted for the balance. Although he recognized that the American Can Company had power over the market, Judge Rose was "frankly reluctant to destroy so finely adjusted an industrial machine as the record shows defendant to be."160 In considering the legal principles involved he asserted that

152. About these arrangements the court said:

"The record amply justifies the assertion that for a year or two after defendant's formation it was practically impossible for any competitor to obtain the most modern, up-to-date, automatic machinery, and that the difficulties in the way of getting such machinery were not altogether removed until the expiration of the six years for Id. at 875 . which the defendant had bound up the leading manufacturers of such machinery."

153. Id. at 897.

154. Id. at 896 .

155. Id. at 881. "The competitors of the defendant are satisfied. . . As has sometimes been suggested, it seems to hold an umbrella over them." Id. at 898.

156. Id. at 903 . 
"one of the designs of the framers of the Anti-Trust Act was to prevent the concentration in a few hands of control over great industries. They preferred a social and industrial state in which there should be many: independent producers. Size and power are themselves facts some of whose consequences do not depend upon the way in which they were created or in which they are used. It is easy to conceive that they might be acquired honestly and used as fairly as men who are in business for the legitimate purpose of making money for themselves and their associates could be expected to use them, human nature being what it is, and for all that constitute a public danger, or at all events give rise to difficult social, industrial and political problems." 167

Then turning his back on his own conception of the Sherman Act, the judge found the American Can's power, though great, was limited by "a large volume of actual competition and to a still greater extent by ... potential competition. . . .'15s In a decree that left American Can's structure undisturbed, Judge Rose expressed the hope that "all potential restraints upon free competition ... will pass away as speedily without as with dissolution." "Dissolution," he said, "will cause far more loss and business disturbance than will attend the gradual re-establishment of competitive conditions by the play of economic forces.'159 Still somewhat uneasy, the court retained the bill and reserved the right to decree dissolution should "the size and power of the defendant" ever be "used to the injury of the public" or should American Can's size and power, "without being intentionally so used," give it "a dominance or control over the industry, or some portion of it, so great as to make dissolution or other restraining decree of the court expedient."10n When the Supreme Court refused to dissolve the United States Steel Corporation in 1920, the Government abandoned its appeal in the Can case. ${ }^{101}$

Did later developments in the industry warrant the court's optimism about the power of existing competition and the development of potential competition? Did the industry become workably competitive? To answer these questions an analysis of the industry's structure, conduct, and performance since the 1916 decision is necessary.

\section{Structure}

The American Can Company today is a far larger concern than it was when the court refused to dissolve it. In 1913 its total sales were $\$ 39,000,000 ;$;62 $^{2}$ in 1954 they were $\$ 652,000,000,{ }^{163}$ an increase of 1,572 per cent. Its share of

157. Id. at 901 .

158. Id. at 903 .

159. United States v. American Can Co., 234 Fed. 1019, 1021 (D. MId. 1916) (decree).

160. Ibid.

161. CCH, The Federal Antitgust Laws Wrte Suararary of Cases, 1890-1951, at 104 (1952).

162. Hession, Competition in the Mietal Food Container Industay 1916-1946, at 39 (1948).

163. Standard \& Poor's Industry Surveys, Containers C4-10 (April 21, 1955). 
total domestic production increased from about one-third in 1913 to over forty per cent in 1946, and in that year it sold 46.4 per cent of all the cans sold in the United States. ${ }^{164}$ Its total assets grew from $\$ 30,500,000$ in $1901^{105}$ to $\$ 432$,000,000 in 1953.166 Except for the sale of $\$ 69,000,000$ in debentures and $\$ 25,000,000$ of common stock, since 1939 American has financed its expansion by the investment of retained earnings. ${ }^{167}$

But the can industry has grown tremendously since 1913, and some companies have expanded more rapidly than American Can. First among its rivals is the Continental Can Company. In 1904 one of the organizers of Americun took the initiative in organizing Continental, when he "and several others decided to break away from the combine" and bought the patents of one of the few canmaking machinery companies not controlled by American. ${ }^{108}$ In 1913 Continental produced approximately one-eighth of the cans produced for sale in the United States-one-fourth as many as American. Its sales totalled $\$ 7,185,000 .^{160}$ By 1954 they totalled $\$ 616,000,000$, , $^{170}$ an increase of 8,700 per cent, and they equalled 92.9 per cent of American's total sales. Together these two companies in 1946 accounted for eighty per cent of all cans made for sale in the United States ; ${ }^{171}$ in 1954 they accounted for seventyone per cent of the industry's nearly $\$ 1,400,000,000$ sales. ${ }^{172}$

American and Continental have in recent years met the rivalry of four medium-sized companies, National Can Corporation, Pacific Can Company (which merged with National in December 1954), ${ }^{173}$ Crown Cork and Seal Company (which in December 1953 merged with its wholly owned stbsidiary, Crown Can Company), and Heekin Can Company, all producing both packers' and general line cans. ${ }^{174}$ In 1946 National, Pacific, Crown, and

164. United States v. American Can Co., 87 F. Supp. 18, $21-22$ (N.D. Cal. 1949).

165. American Can paid about $\$ 23,500,000$ for the ninety-five plants turned over to it "on the day after it was organized." United States v. American Can Co., 230 Fed. 859, 870 (D. Md. 1916). "The promoters were to furnish $\$ 7,000,000$ cash, or, in all, in stock and money they were to lay out $\$ 30,500,000$, for which they received $\$ 39,000,000$ preferred and $\$ 39,000,000$ of common stock." Id. at 873 . Most of the new company's cash went into the purchase of stocks of merchandise in the plants it took over, and "it really began life without a free dollar to its name,..." Id. at 874 .

166. Moody's Industrials 1733-36 (1954).

167. Ibid.

168. Sheehan, Continental Can's Big Push, Fortune, April 1955, p. 121.

169. Hession, Conpetition in the Metal Food Container Industry 1916-1946, at 39 (1948).

170. Standard \& Poor's Industry Surveys, Containers C4-11 (April 21, 1955).

171. United States v. American Can Co., 87 F. Supp. 18, 22 (N.D. Cal. 1949).

172. Standard \& Poor's Industry Surveys, Containers C4-5 (April 21, 1955).

173. National Can Corporation purchased the capital stock of Pacific Can Company at $\$ 28.57$ a share. The merger combined twelve plants expected to have a total annual sales volume of more than $\$ 80,000,000$. N.Y. Times, Dec. 24,1954 , p. 20 , col. 2.

174. Packers' cans, sometimes called sanitary cans, are closed by machines and are used in the packing of fruits and vegetables. General line cans embrace a large number of specialized cans, the most important being those used in canning cofiee, shortening, beer, motor oil, and chemicals. Although American is the major mantufacturer of cans for boer, 
Heekin together accounted for only 13.6 per cent of the total can sales in the United States; ${ }^{175}$ with American and Continental they accounted for 93.6 per cent. Threescore or more minor companies, most of them producing only general line cans, accounted for the remaining 6.4 per cent. ${ }^{170}$ Those that produce packers' cans frequently do so for a single canning company, to which they are a sort of satellite.

That two companies accounted for approximately eighty per cent of the cans sold in the United States in 1946 and four more for most of the remainder, does not reveal adequately the significance of structure to competition in the sale of cans. Because cans are bulky and transportation costs relatively heavy, they are generally sold in local or regional markets from plants located close to their customers. American, with fifty-eight widely scattered can factories, ${ }^{177}$ sells in all United States markets and in Hawaii, Alaska, and Canada as well. Continental-and only Continental-with forty-one can factories, ${ }^{178}$ challenges American's leadership in most of these markets. American has supplied virtually the entire sardine canning industry in Maine from its plant at Lubec. ${ }^{170}$ In Utah and Hawaii American has a complete monopoly, and in Alaska it has eighty per cent of the business. ${ }^{180}$ In California the National-Pacific combine is the only substantial rival of American and Continental, and in the Pacific Northwest, American and Continental meet no effective competition. ${ }^{181}$

Canmaking is highly concentrated, but canmakers meet no similar concentration on the buying side of the market. They sell packers' cans to thousands of food canners. These are widely distributed throughout the country, with a tendency to cluster around the production center of the crop they pack. Few are large enough to exert any influence on the price of cans, but some large buyers have been able to get cans on better terms than their smaller rivals. In 1941 American's fifteen largest purchasers bought only about onethird (in dollar value) of all the cans it sold; six companies bought about

coffee, shortening, and meat, conditions of entry and economics of scale in the making of general line cans permit small manufacturers to get into this sector of the industry more easily than into the making of packers' cans.

175. United States v. American Can Co., 87 F. Supp. 18, 22 (N.D. Cal. 1949).

176. Id. at $22 \mathrm{n}$.9. Sheehan, stipra note 168, at 122, places the number of small, regional canmakers operating today at "eighty-add." Standard \& Poor's say there are approximately 100 active companies in the metal can field, "about one-third of which are pachers operating captive plants." Standard \& Poor's Industry Surveys, Containers C4-5 (April 21, 1955).

177. In addition to its metal container plants American operates three fiber can and package plants and eight factories for the manufacture and repair of canmaking machinery: MIOODY's INDUSTRIAIs 1734 (1954).

178. Continental also has fourteen fiber and paper container plants, nine bag and flexible package material plants, three crown cap plants, two defense plants, one plastic plant, and eight factories for the manufacture and repair of canmaking machinery. Id. at 2159.

179. Hession, The Tin Can Industry, in Tre Structure of Aserica: I:noustay 409 (Adams ed., rev, ed. 1954).

180. United States v. American Can Co., 87 F. Supp. 18, 23 (N.D. Cal. 1949).

181. Hession, The Tin Can Industry, in The Structure of Aurnican Industry 409 (Adams ed, rev. ed. 1954). 
forty-two per cent of the packers' cans American sold. ${ }^{182}$ Continental's selling was probably less concentrated. Three of the country's four largest canners packed only thirteen per cent of the country's canned vegetables and thirty per cent of its canned fruit in 1937. ${ }^{183}$ Thousands of other canners accounted for the balance. Decentralization in food canning suggests that countervailing power affords inadequate protection against such power as the two big canmakers may have.

But entry, into canmaking is relatively easy. Canmaking on an economical scale requires a relatively small amount of capital. ${ }^{184}$ Control of neither patents nor canmaking machinery affords a serious obstacle to entry. ${ }^{185}$ On the other hand, while the technological optimum is relatively small, a firm with several plants so located that cross-shipments are not exorbitant can more readily meet the seasonal demands of its customers than can single-plant firms. Moreover, the firm large enough to engage in research in canmaking and can using has a distinct advantage over the smaller firm. Service to canners and the development of cans for new uses are important functions of the larger canmakers. But the principal obstacle to the growth of smaller firms has been the conduct of the large ones.

\section{Conduct}

In 1916 the district court found that the American Can Company had discontinued such of its conduct as reflected an intent to monopolize. As the court put it, " $[N]$ obody in the trade feels that the defendant is hurting anybody, or for a number of years past has hurt anybody, or has tried to."180

Yet as previously stated, American Can's superior bargaining power had enabled it to get secret rebates from the American Sheet and Tin Plate Company in buying tin plate. ${ }^{187}$ The cost of tin plate is the largest single item of expense in making cans, constituting approximately sixty-five per cent of the

182. These calculations are based on data appearing in Professor James W. McKie's forthcoming study of the metal container industry. The data are from Exhibits 63 and 3124, United States v. American Can Co., 87 F. Supp. 18 (N.D. Cal. 1949).

183. Hession, The Tin Can Industry, in The Structure of American Industry 410 (Adams ed., rev. ed. 1954).

184. According to McKie's study, supra note 182, a general line can plant with elght production lines and an annual capacity of $500,000,000$ cans would cost about $\$ 7,000,000$, including land, buildings, machinery, and lithographing equipment. A packers' can plant not requiring lithographing equipment would no doubt cost less but because of seasonal variation in demand would probably produce only half as many cans.

185. No basic patents block entry, but the leading producers have many improvement patents-American's and Continental's running into the hundreds. Crown Can Company apparently had little difficulty in getting the necessary machinery when it went into business in 1936. Hession credited an executive of American Can with saying that no other can manufacturer really needs American's patents. They have their own. Hession, Competition in the Metal. Foód Container Industry 1916-1946, at 169 (1948).

186. United States v. American Can Co., 230 Fed. 859, 897 (D. Md. 1916).

187. American's top executives had taken great pains to conceal its favored treatment not only from the trade but from other company executives as well. Only two of them 
total cost. American Can's secret rebate amounted to about sixty-four cents on the tin plate required to make 1,000 3-pound packers' cans. This, as the court put, was "far from negligible" and in the competitive struggle "might well have proved a decisive factor."188 But the court found that "the preferential ended in April, 1913, some seven months before this suit was brought."183 Despite the court's finding, two decades later negotiations on the Steel Code under the National Recovery Administration revealed that American Can was again receiving a secret concession-71/2 per cent-in buying tin plate from Carnegie-Illinois Steel Corporation (American Sheet and Tin Plate's successor and a United States Steel Corporation subsidiary). ${ }^{100}$

While American Can was receiving confidential discounts from the "official" price of tin plate, it was tying its can prices to published tin plate prices. ${ }^{101}$ Each year Carnegie-Illinois and American Can negotiated the official price, which became the price at which Carnegie-Illinois and other tin plate companies offered tin plate to all other buyers. Other large canmakers followed American Can's lead in tying tin can prices to tin plate prices. American Can in this way for many years was the price leader. The smaller canmaking companies, whose service to canners is far less adequate, customarily sold at slightly lower prices. Continental, though generally selling at prices identical with those of American, did not always rely on its independent discretion in doing so. In truth, at times it has apparently conspired with American in fixing prices, allocating customers, dividing markets, and assigning fields of production. At any rate on June 26,1946 , a federal grand jury indicted both American and Continental and seven of their officers on a charge of criminal conspiracy. ${ }^{192}$ All the defendants pleaded nolo contendere and on January 28, 1947 paid maximum fines under the Sherman Act.

Two years later a district court in civil proceedings against American and Continental concluded:

"The pattern of evidence herein suggests more than a following un the part of Continental of the prices fixed and established by Ameriean. . . .

were in on it. TNEC, Investigation of Concentration of Ecososic Power, Hearings, pt. 20 , at 10789 (1939).

188. United States v. American Can Co., 230 Fed. 859, 875 (D. Md. 1916).

189. Id. at 885 .

190. TNEC, Investigation of Concentration of Econimic Power, Hcarings, pt. 20 , at 10777-7S (1939). When the code of fair competition for the steel industry made this discount applicable to the trade generally, American Can insisted that under its contract with Carnegie-Illinois it was entitled to a further discount of $7 \% / 2 \%$. When the steel company rejected this interpretation, American Can filed suit. In an out-of-court settlement Carnegie-Illinois paid American $\$ 2,250,000$. Id. at 10778-79.

191. Before 1939, in contracts with its customers American Can stated the price for each standard size of packers' cans and established a scale of differcntials for increasing or decreasing can prices with each $10 \mathrm{c}$ change in Carnegie-Illinois' official price per base box of 100-pound coke plate, $14^{\prime \prime} \times 20^{\prime \prime}, 112$ sheets to the box, f.o.b. mill, Pittsburgh, $\mathrm{Pa}$. TNEC, Investigation of Concentration of Econonic Power, Hearings, pt. 20, at 10763 (1939).

192. United States v. American Can Co., Cr. No. 30323-S (N.D. Cal. June 26, 1946). 
American and Continental, through their officers, agents, and servants, did directly agree to fix prices. This is manifest from the evidence, as well as the pattern of the price lists which appeared in the exhibits."104

In reaching this conclusion the court quoted Justice Douglas's characterization of such arrangements as "monopoly competition"-_a regime of friendly alliances, of quick and easy accommodation of prices even without the benefit of trade associations, of what Brandeis said was euphemistically called 'cooperation." "104

While serving as a price leader in the industry, American Can engaged in other practices inconsistent with workable competition. Fifteen months after the court had refused to destroy "so finely adjusted" an industrial machine, a Federal Trade Commission investigation revealed that American Can was requiring the lessees of its closing machines (which it leased but would not sell) to buy cans exclusively from it. ${ }^{105}$ American Can agreed to climinate the tying clause, and on April 29, 1924, the Federal Trade Commission dismissed its complaint. 196 A quarter of a century later a federal district court found that American Can was accomplishing indirectly what it had previously achieved directly by contract. ${ }^{197}$ In leasing its closing machines American timed the lease to any customer to run concurrently with the customer's contract for the purchase of cans. In selling cans it generally contracted to supply a customer's total requirements for long periods of time (three to twenty years throughout much of American Can's existence, and a standard five years shortly before the 1949 antitrust case), and it leased closing matchines only to its own customers. American Can's executives coached its salesmen to include no tying clause in a lease but to make certain that the terminable dates for a customer's lease and for its requirements contract should be the same. If a customer did not renew its purchase contract, American Can did not renew its lease. Most of American Can's closing machines were not protected by patents, and with a slight adjustment could be used to close cans made by other manufacturers; and so American charged below-cost rentals for its machines, in order to foreclose competition from other machinery makers and to keep its lessees content with its system of tying the leases to its longterm requirements contracts. ${ }^{198}$ In this way American Can continued to be

193. United States v. American Can Co., 87 F. Supp. 18, 33-34 (N.D. Cal. 1949).

194. Standard Oil Co. v. United States, 337 U.S. 293, 318 (1949), quoted in United States v. American Can Co., supra note 193, at 33.

195. Apparently the FTC did not publish a report on its 1917 investigation of American Can. The district court described its outcome in United States v. American Can Co., 87 F. Supp. 18, 25 (N.D. Cal. 1949).

196. The complaint, issued May 1, 1918, had also charged American Can with discriminating in price and using long-term contracts to stifle competition. The Commission did not assign reasons for dismissing it. The American Can Co., 7 F.T.C. 541 (1924).

197. United States v. American Can Co., 87 F. Supp. 18 (N.D. Cal. 1949). Statements of fact in the rest of the paragraph are based on this opinion.

198. The court found that this practice "has tended to restrict the market for closing machine manufacturers and has limited the number of concerns engaged in this business." 
the sole supplier of most of its customers, and in addition made it difficult for new canmakers to get into business and for those already in it to grow. ${ }^{103}$

The conduct of the leading firms has made it difficult for other can sellers to grow. Have can buyers fared better? Lawsuits against American Can reveal that by discriminating among its customers in pricing and servicing cans it has placed small canners at a disadvantage. It has favored large buyers by secret discounts, has loaned them its closing machines without charge, and has granted them bonuses and special allowances. The courts have found that its preferential prices were not justified by differences in costs nor made in good faith to meet competition. ${ }^{200}$ Such practices reflect in part the greater buying power of the large canners, who continuously hold over their suppliers the threat of making their own cans ${ }^{201}$ and who with Continental's growth have been able to play Continental against American Can. After court proceedings exposed American's discriminatory practices and some of the injured parties collected treble damages, American tried to bring its practices within the law. At any rate, it established quantity discounts and made them available to any buyer who qualified; but by basing its discounts on annual cumulative purchases it placed them beyond the reach of small buyers and in 1949 the district court held this practice unlawful.

On the whole, American Can's conduct since the 1916 decision has scarcely justified the court's optimism about the restoration of a free market. What about its performance?

\section{Performance}

By negotiating the price of tin plate annually, and tying the price of tin cans to it, American Can made the price of tin cans relatively stable: tin can prices have customarily remained unchanged throughout the calendar year and sometimes for considerably longer periods. ${ }^{202}$

United States v. American Can Co., 87 F. Supp. 18, 24 (N.D. Cal. 1949). The court quoted the government's brief for the point that of the thirty-four canmakers named as "competitors" of American Can in the trial examiner's report on the facts in the Federal Trade Commission's 1924 proceedings, see note 196 supra, only six "are now in cxistence, a mortality rate of $82 \%$." United States v. American Can Co., supra at 22 n.9.

199. The court concluded that "the five year requirements contracts and closing machine leases unreasonably restrain trade in violation of the Sherman Act. The evidence discloses that competitors have been foreclosed from a substantial market by the contracts and leases." Id. at 29.

200. George Van Camp \& Sons Co. v. American Can Co., 278 U.S. 245 (1929); American Can Co. v. Ladoga Canning Co., 44 F.2d 763 (7th Cir. 1930); Bruce's Juices, Inc. v. American Can Co., 87 F. Supp. 985 (S.D. Fla. 1949), aff'd, 187 F.2d 919 (5th Cir.), cert. disnissed, 342 U.S. 875 (1951); Russellville Canning Co. v. American Can Co., 87 F. Supp. 484 (W.D. Ark. 1949), revid, 191 F.2d 38 (8th Cir. 1951) (plaintiff failed to establish ascertainable damage proximately resulting from discriminations).

201. Among the large packers who now make their cans are Campbell Soup, the country's third largest canmaker, Heinz, Pet Milk, Carnation Co., Sherwin-Williams, and Texas Co. Standard \& Poor's Industry Surveys, Containers C4-5 (April 21, 1955).

202. They were stable throughout 1924 and 1925 and at a slightly lower level throughout 1926 and 1927; they dropped again in 1928 but showed little change through 1929, 
Stability in can prices throughout the canning season eliminates risk and speculation in buying cans and contributes to a more orderly marketing of tin cans and of canned foods, but cyclical and secular stability in can prices has no such virtue. Stable prices in the face of long-run changes in demand and cost functions interfere with the effectiveness of the pricing mechanism. They tend to place the burden of readjustments to changing demand-supply relationships largely on the canners, to the benefit of the canmakers. Tin cans cost almost as much as the food they contain: in 1918, for example, canners paid thirty-three cents for a dozen No. 2 cans; but they paid only thirty-four cents for the corn to fill them, and thirty-six cents for the same amount of string beans. ${ }^{203}$ Between 1929 and their depression lows the wholesale prices of canned vegetables and fruits fell twenty-five per cent and forty per cent respectively, while between 1929 and 1933 American Can's published prices for No. 2 cans declined less than thirteen per cent. By 1934 canned vegetable prices had risen about six per cent above their 1932 level and canned fruit prices about twenty-two per cent; the price of No. 2 cans had risen to within less than half of one per cent of the 1929 level. The prices of canned fruits and vegetables fell sharply in 1935 and 1937 and reached their low points in 1938 ; in 1938 American's published price of No. 2 cans rose slightly. ${ }^{204}$ Competition among food growers and food canners has traditionally been very effective, and in the absence of governmental controls neither group has had a mechanism for shielding itself from the impact of market forces. Such price behavior not only placed canners at a sharp economic disadvantage; it no doubt contributed to the high mortality rate in the canning industry. ${ }^{205}$

1930, and 1931; they were lower in 1932 and reached their depression low point in 1933. They were sharply higher by 1934 and remained unchanged until the end of 1936 . In 1937 they fell to their 1933 level, at which level after minor fluctuations they were stabilized by wartime controls. Hession, The Tin Can Industry, in The Structure of Auerican INDUSTRY 423 (Adams ed., rev. ed. 1954).

203. FTC, Report on CanNed Foods tables 4, 8, at 26, 30 (1918).

204. Hession, Conpetition in the Metal Food Container Industry 1916-1946, charts VI, VII, at 222, 227 (1948). Apparently embarrassed by the disparity between their earnings and those of their customers, see note 205 infra, canmakers granted their customers "rebates equivalent to 25 cents a box on tin plate purchases for 1938." Poor's IndustnY AND InvestMent SuRveys, Container Manufacturing C3-8 (Dec. 19, 1940).

205. While some canners had prospered, a survey by the National Canners Association reveals that by 1938 more than half the canners in business at the beginning of 1929 had disappeared. The study recognized that not all disappearances represented liquidation. Some were due to changes of name, death of owners, mergers, and the like. But it concluded that the actual annual mortality rate in the years covered was about $7 \%$. National Canners Association, Some Phases of the Canning Industry, Supplement to the Information Letter, Jan. 3, 1.942, quoted in Hession, CoMpetition IN THE METAL. Food Container INDustry 1916-1946, at $254 \mathrm{n} .69$ (1948). Fortune in 1934 in commenting on the divergence of price behavior had the following to say:

"American and Continental make cans, but they never fill them. That is the canner's job. And the canner is at present an extremely depressed individual. Van Camp's is in bankruptcy. Hawaiian Pineapple has been reorganized . . ., Libby, McNeil \& Libby, operating sixty-three canneries, lost $\$ 6,248,000$ for the ycar end- 
But the canners were not the only ones to suffer from the failure of can prices to respond more promptly to market forces. Between 1934 and 1939 out of every dollar spent at wholesale for canned tomatoes, corn, and peas in No. 2 cans, from 22.5 to 40.6 cents went to can manufacturers. ${ }^{-00}$ Assuming that on the average the cost of cans represents thirty per cent of the total cost of canned foods, and taking 1939 consumption as a normal year, a three per cent reduction in the price of cans if passed on to consumers would have reduced their living costs by $\$ 6,000,000$ a year. ${ }^{207}$ Plagued as the country was by unemployment and low national income during the 1930 's, such a price reduction would without doubt have contributed to the general welfare.

While canners and consumers were adversely affected by the conduct of American Can, the company fared relatively well. During the ten years from 1930 through 1939 its net revenue averaged 9.7 per cent on its capitalization; and although between 1929 and 1932 American's rate of earnings declined by more than fifty per cent, it earned over six per cent on its capitalization..$^{\text {ns }}$ During the same period the net income of 728 industrial companies declined ninety-four per cent, and many of them suffered severe losses. ${ }^{200}$ During the generally more prosperous years 1922-1928 inclusive American earned at a slightly higher rate, 10.1 per cent. This compared with an average return of 9.7 per cent for 2,046 manufacturing corporations. 210

An examination of American's contribution to the advance of technology reveals a better picture. It has taken its research opportunities seriously and has improved both the making and the use of cans. It opened its first laboratory in 1906 with a research staff of thirty-five. In 1926 it launched its central laboratory at Maywood, Illinois, operating on a far larger scale. By developing the Johnson double-seamer and the so-called inverted type of lock and lap seam it made the manufacture of cans almost wholly automatic. ${ }^{211} \mathrm{By}$ substituting the "roll form" body-maker for the "wing form," American increased can output per machine from 150 cans a minute to 200 , later to 300 , and

ing March 4, 1933. Hundreds of small canners have gone out of business. But the can maker is still prosperous. ... [T] [ the two big container corporations ... are embarrassed because they are so much more prosperous than their customers and none release sales figures for fear that the customers might want them to reduce their prices."

“Profits in Cans," Fortune, April, 1934, pp. 77-78.

206. TNEC, Investigation of Concentration of Econonic Power, Hearisgs, pt. 20, exhibit No. 1402, at 10989 (1939).

207. Computed from data in U.S. Dep't of Cosmerce, Statistical Abstract of tuF UNited States 648, 695 (1943). The wholesale value of canned food produced in 193') amounted to roughly $\$ 700,000,000$.

208. These calculations are based on Hession, Courpetriox in tae Mietal Food CONTATNER INDUSTRY 1916-1946, table 26, at 245 (1948).

209. Id. at 160 .

210. Id. at 159; Epstenn, Industrlal Profits in the United States 56 (1934).

211. Hession, Conpetition in the Metal Foon Coxtainer Ixdustis: 1916-1946, at 277 (1948). 
eventually to $400 .^{212}$ Cooperating with steel companies, its research staff has greatly improved the quality of tin plate. It has encouraged its employees to perfect new ideas: in 1943 alone they obtained over a hundred patents, to that date an all-time record. ${ }^{213}$ Its service to canners has been a distinctive feature of its sales technique. Its sales engineering division has assisted in installing the company's machines in customers' plants and in designing the most efficient plant layout. In short, American has been a pacemaker in technology. ${ }^{214}$ Only Continental has rivaled it in this field.

But in evaluating its conduct and overall performance it is difficult to see how economists could characterize the industry as having been workably competitive. Those who know it best have not done so. ${ }^{215}$ Nor did a federal court in 1949. The court recognized that American as price leader dominated the can market and that the preferential treatment given big buyers-together with American's long-term requirements contracts and its practice of coordinating and timing its closing machine leases with its purchase contracts -had served as an effective obstacle to entry and had blocked expansion by small companies. 216

\section{The 1950 Antitrust Decrees}

The consequences of the 1950 decrees against both Continental and American ${ }^{217}$ seem to have demonstrated the validity of the district court's findings. The decrees prohibited American and Continental from offering buyers annual cumulative volume discounts or discriminating among buyers except on a

212. Id. at 261.

213. Id. at 171 .

214. It still is. When the Korean hostilities and the government's stockpiling led to shortages of tin, American Can developed special coatings which permanently replaced tin in some applications. In 1954 it reported that the motor oil industry was using almost exclusively cans containing no tin or solder. STANDARd \& Poor's Industry Survers, Containers C4-2 (April 21, 1955).

215. Hession in discussing "the record in retrospect" in 1954 stated: "Our study discloses that Continental Can has grown, but American Can has not declined relatively, so that a condition of near-duopoly has been created. ... [P]rice leadership and price stabilization ... has [sic] denied canners and consumers most of the savings made possible by technological progress." Hession, The Tin Can Industry, in The Structune or Amentcan INDUSTRY 432 (Adams ed., rev. ed. 1954). Hession recognized obstacles to entry as having been one of the principal obstacles to workable competition and characterized the 1950 antitrust decrees as "a major effort to correct this condition." Id. at 441. About the prospects he expressed a wait-and-see attitude. McKie's analysis of developments since the decree is more optimistic. He concludes, "A forecast of workable competition appears to be justified." McKie, The Declite of Montopoly in the Metal Container Industry, 45 Axr. ECon. Rev. 499, 508 (1955).

216. United States v. American Can Co., 87 F. Supp. 18 (N.D. Cal. 1949).

217. Continental on June 26,1950 , agreed to a consent decree imposing substantially the same prohibitions on it as those imposed on American. United States v. Continental Can Co., 1950-1951 Trade Cas. $\llbracket 62680$ (N.D. Cal. 1950). The decree against American was filed June 22, 1950. United States v. American Can Co., 1950-1951 Trade Cas. \&62679 (N.D. Cal. 1950). 
basis of actual cost savings; from entering into requirements contracts extending beyond a year; and from conditioning the sale or lease of closing machines on the use of the lessor's cans directly or by any subterfuge. The court also ordered each defendant to sell such closing machines as it then had, giving preference to existing lessees, and any it might build within ten years. According to McKie the industry has promptly taken advantage of the opportunities that the decrees have opened to it, and the industry's performance reflects its greater freedom. He finds that by the middle of 1954 canners had bought over seventy-five per cent of the closing machines they held under lease from American and Continental in 1950; that the abandonment of leasing will broaden markets for the independent closing machine manufacturers; that exclusive supplier-customer relations are breaking down; that open-order purchasing has greatly increased; that small firms are now getting a part of the business previously done by the large suppliers and their market position has thereby been greatly strengthened; that tin plate prices are becoming more flexible and open-order purchasing of tin plate has increased; that rivalry between American and Continental has intensified; that American's price leadership has become wholly barometric; and that the inability of the dominant firms to give large canners preferential treatment is making the threat of integration a more effective check against their exploiting the market..18

All economists may not share McKie's optimism, ${ }^{210}$ but few are likely to challenge the implication of his analysis-that until the relief afforded by the court in 1950 the industry had not been workably competitive. Whatever its future, canmaking as judged by the criteria applied in this article-structure, conduct, performance-had not met the requirements of workable competition. The industry's oligopolistic structure contributed to practices that led to economically unacceptable performance. ${ }^{220}$

\section{Conclusions}

If the foregoing analysis is sound, application of the principle of workable competition under the rule of reason would obligate the courts to examine

218. McKie, sutpra note 215 , at $505-07$.

219. Hession, writing about a year earlier than McKie, was more restrained in his evaluation of the significance of the decree. Hession, The Tin Can Industry, in Tue. Structure of Aarerican Industry 437-41 (Adams ed, rev. ed. 1954). So was Stakd.18d \& Poor's Industry Surveys, Containers C4-5 (April 21, 1955):

"The possibility that newcomers may make important inroads into the business of large can companies is small. On the one hand, a large part of the business is done on the basis of contracts, and, on the other, capping and sealing machinery are leased by the companies which supply the cans, with users having the right of purchase since June, 1950. In addition, plants of existing concerns generally are strategically located in important consuming areas."

McKie of course did not base his optimism on the probable entry of neweomers other than through backward integration of canners.

220. Whether the public interest would be better served by dissolution of American and Continental, both of which might be brought within the prohibitions of the Sherman 
all facts relevant to determining whether a combination hinders the operation of market forces or whether a firm is monopolizing a market; but having found either to be the case, the courts would have no discretion in assessing the social desirability of such hindrances or in passing on the reasonableness of arrangements designed to control markets. Such an obligation, so restricted, might have resulted in decisions adverse to the corporations here considered. It might have led to a more, not a less, vigorous antitrust policy. It might have brought within the purview of the Sherman Act combinations that the 1911 decisions placed beyond its reach.

But might not even the application of these principles still leave beyond the law's reach market structures that are dominated by neither a combination nor a monopoly but that when judged by the number and relative size of firms and their conduct and performance do not meet the tests of workable competition? Some firms operating within an oligopolistic market structure might not be regarded as combinations, except perhaps in an "archeological" sense; nor as monopolies within the meaning of section 2 of the Sherman Act as interpreted by Judge Hand in the Aluminum case. They may have been created originally by combining rival firms, but their growth in recent years may have been primarily by internal expansion. How can such firms in an industry that does not meet the tests of workable competition as herein developed be brought within the scope of the act?

The courts, tending to look to conduct alone, have sometimes been reluctant to disturb restrictive structures and arrangements because their origins are "archeological." But this analysis has suggested that oligopolistic structure, as a continuously operative fact, may be conducive to conduct and performance that are inconsistent with the objectives of the Sherman Act. For example, the outstanding contemporary feature of the steel industry's structure-the existence of the United States Steel Corporation-came into being many years ago, when the Steel Corporation was formed by the combination of numerous originally independent firms. The Steel Corporation's overtowering size in relation to other companies in the industry, and the relative fewness of its rivals, have contributed to its leadership in pricing steel and to its rivals' acceptance of that leadership; to the collective and systematic use of basing point pricing; to collaboration in determining the average costs of extras and in pricing them. Not only has the structure of the industry facilitated these practices, but the practices have contributed to unacceptable industry performance. A consideration of all the circumstances at work in an industry-as the

Act should Congress see fit to incorporate the rule of reason and the principle of workable competition in it, is a matter of conjecture, and one's conjecture about it is apt to be greatly influenced by his preconceptions. I believe that dissolution would re-establish an industrial structure more consistent with the objectives of the Sherman Act. McKic, illthough recognizing that "several firms could have been fashioned out of either of the leaders without an appreciable loss of efficiency," and that thereafter "the market would in time have enforced a high degree of competition," perhaps correctly concludes that under existing law a monopoly charge could not be sustained; and as indicated above, he believes the 1950 decrees will provide adequate remedies. McKie, supra note 215, at 507 . 
rule of reason would require-should lead the courts to attach great significance to the continuing interaction of structure and conduct in determining the legality of the practices pursued and in shaping remedies for an industry found not to be workably competitive. That the structure rests on old combinations should not hallow it in the light of a law designed to assure competitive conditions here and now.

A more realistic interpretation of the Sherman Act's prohibition of conspiracies in restraint of trade and of attempts to monopolize provides yet another way of bringing oligopolistic structures that do not meet the tests of workable competition within the act's reach. What business firms are up to is relevant in determining whether they violate the law. If the sellers in a market of few firms adopt a strategy designed to preserve the market's oligopolistic character by blocking entry and handicapping rivals, or to substitute collective patterns of behavior for independent decision-making, clearly they should be found to violate section 1 of the Sherman Act, as engaging in a conspiracy in restraint of trade. The courts might properly find a conspiracy from the total configuration of the contracts and practices employed even though no one of them was illegal per se. Likewise if a dominant firm pursues a course of conduct as a result of which imports of competing products are restricted; if patent infringement suits are used to bring would-be competitors to terms; and if patent license agreements become the means of dividing markets, the courts might properly find in such acts an attempt to monopolize within section 2 of the Sherman Act. In doing so, of course, they must apply a less rigid conception of monopoly than that advanced in Alumimum-the firm's control of any given percentage of the relevant market. Oligopoly is not necessarily incompatible with workable competition; but when the facts establish that it is, it should be treated like monopoly.

Where structure exerts a continuing pernicious influence on conduct, fines and injunctions against law violators may prove inadequate to insure workable competition. A change in structure may be called for. Dissolution proceedings might pave the way to more acceptable industry performance. Such proceedings should be aimed at creating not an atomistic industrial structure, but the sort of structure that would have arisen had the firms in the industry not resorted to competition-suppressing tactics. Penalizing bad conduct is unlikely to reform it where an industry's structure makes it both effective and profitable. In such situations the courts should help establish a new architecture in which restrictive practices are unlikely to be inevitable or even to flourish.

It may be difficult to attain an interpretation and application of the concept of workable competition as it has been expounded here. Amendment of the law is unlikely to be the solution: many of the advocates of change apparently hope for a gentler, not a more rigorous, application of the statutes to big business. The concept of workable competition is vague, and differences among experts as to its meaning are inevitable. As Mason has suggested, the 
preconceptions of the analyst as well as the facts may influence his judgment on the competitive workability of any particular arrangement. ${ }^{221}$

If amendment of the Sherman Act is an inadequate solution, judicial broadening of the act to include the concept of workable competition, however desirable it may seem in theory, may not prove in fact a more promising remedy. As has been pointed out, without any change in the statute the doctrine of workable competition is creeping into the decisions. This is strikingly evident in Judge Leahy's decision in the Cellophane case, which reveals how a superficial understanding of the concept and its application to a particular set of facts may defeat the objectives of the Sherman Act. If this decision becomes a precedent, it will be difficult to establish the existence of monopoly in any industry confronted by rival products that for some uses may be substitutable and among which a vigorous rivalry appears to exist.

Judges no less than economists may be influenced as much by the totality of their experience and by the institutional matrix in which they formulate their ideas as they are by the logic of a particular situation. Judges and economists live in an economy of big business units, and most of them have learned to like it. Any proposal to disturb these "finely adjusted industrial machines" would encounter serious institutional obstacles. The American private enterprise system in the past decade and a half has earned the admiration and envy of the civilized world, and many Americans have accepted the easy explanation that giant industrial units are responsible for the gigantic achievements of the American economy. This belief is rapidly becoming a part of the American folklore. But in truth, the causes of the striking technological progress in this country and of the high standards of living it has brought are complex. The spirit of enterprise, the bold initiative of business leaders in a general atmosphere of freedom, a technology enriched by the unhampered achievements of scientists and engineers throughout a half-century or more, and the expansive force of deficit financing occasioned by hot wars and a continuing cold war, have all contributed to it. In short, the recent achievement of American capitalism is a phenomenon larger than the firms that have played a role in it. The contemporary bigness of firms is perhaps as much an effect as a cause of this achievement.

I believe, although I cannot prove, that the economic achievements of the last fifteen years would have been in no way impaired and that economic opportunities would have broadened and multiplied had business units been somewhat smaller and more numerous-if the economy had boasted more big firms but fewer industrial giants. And I believe that applying the concept of workable competition as herein expounded in enforcing the antitrust laws would have contributed to such a development. Many people will reject the thesis that giantism in business is not the essential element in America's economic progress-it will be least acceptable to representatives of the industrial giants themselves. "What a dust I raise," said the fly on the chariot wheel.

221. "It seems probable that individual judgments will always be influenced to some extent by ideological considerations." Mason, The Current Status of the Monopoly Prolilem in the United States, 62 HARv. L. REv. 1265, 1283 (1949). 


\section{THE YALE LAW JOURNAL}

\begin{tabular}{lll}
\hline Voluare 64 & JULY, 1955 & Nuarber 8 \\
\hline
\end{tabular}

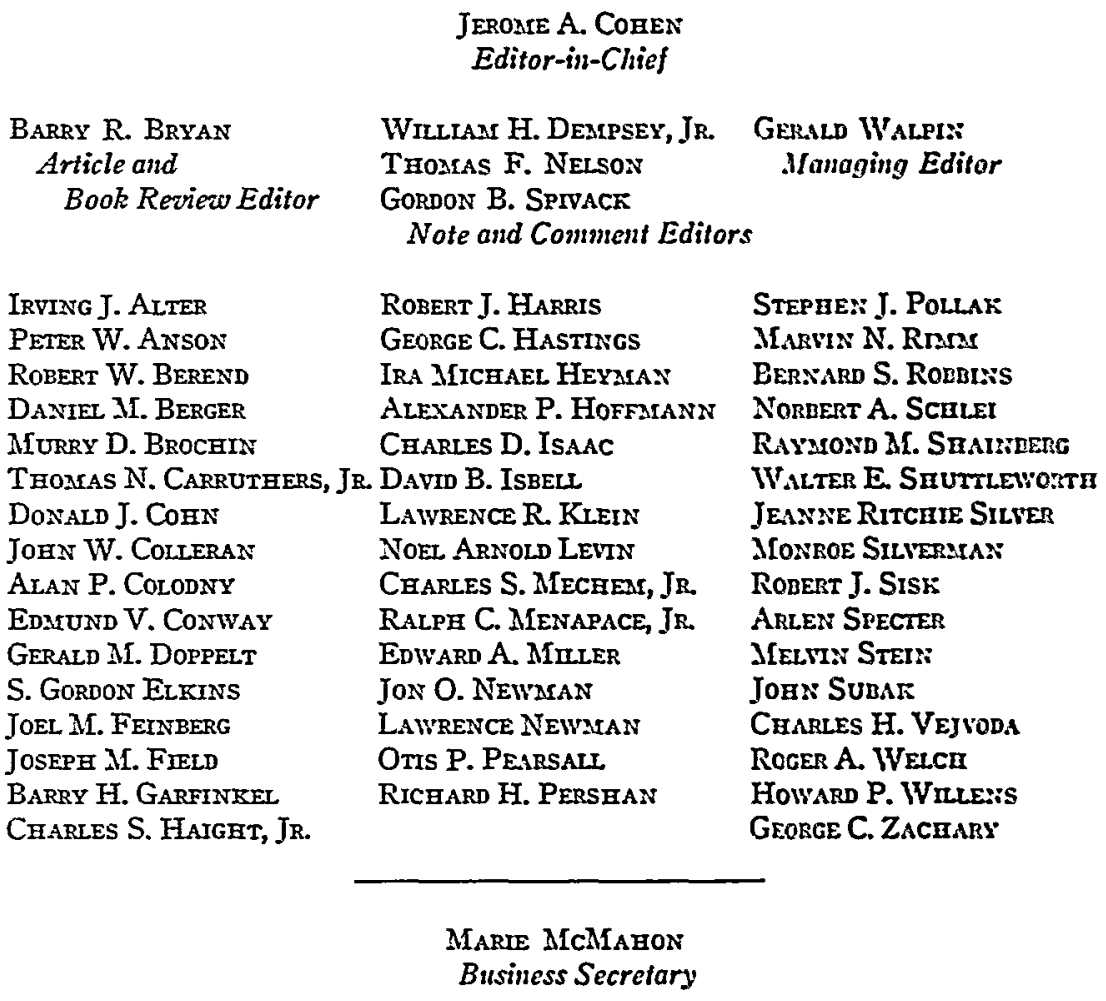

\section{CONTRIBUTORS TO THIS ISSUE}

Charles E. Ctark. B.A. 1911, LL.B. 1913, Yale University. Chief Judge, United States Court of Appeals, Second Circuit.

Richard C. Donneluy. Ph.B. 1936, LL.B. 1938, Washburn University; J.S.D. 1949, Yale University. Professor of Law, Yale Law School.

Grorge W. Stacking. B.A. 1918, University of Texas; M.A. 1921, Columbir University; Ph.D. 1925, Columbia University. Director, Institute of Research and Training in the Social Sciences; Chairman, Department of Economics and Business Administration, Vanderbilt University. Author: The OnL Industry and the Cosrpetrtrve Systens (1925); Potash-A Study in State Control (1930); Basing Point Prictivg and Reglonal Deyeloparent (1954). Co-author (Watkins): Carteis in Action (1946); Cartals o3 Conpetrtion? (1948); Monopoly' ANd Free Enterpaise (1951). 